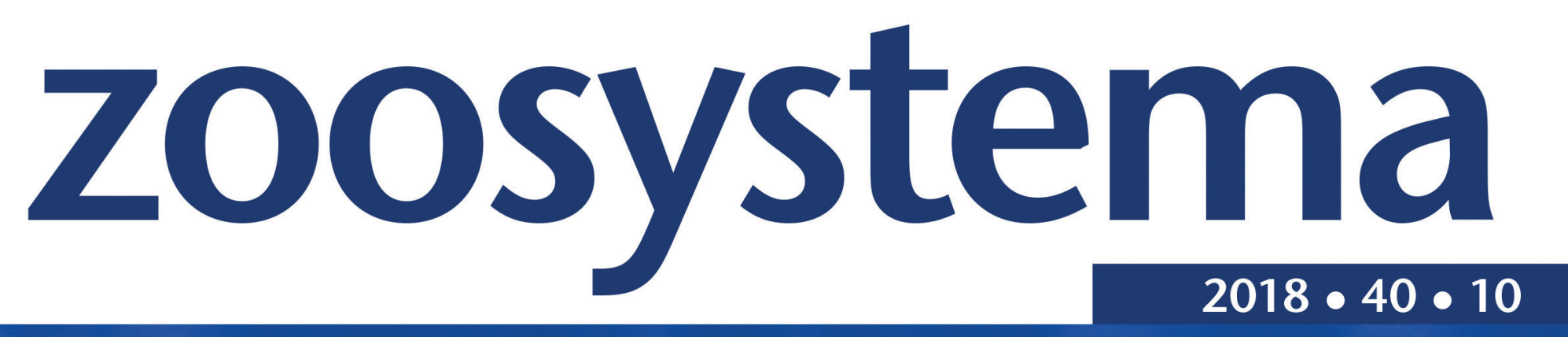

\title{
Annotated checklist of Afrotropical Trogolaphysa Mills, 1938 (Hexapoda: Collembola: Paronellidae) and description of a new species from Madagascar
}

Minh NGUYEN \& Felipe N. SOTO-ADAMES 
DiRECTEUR DE LA PUBlication: Bruno David

Président du Muséum national d'Histoire naturelle

RÉDACTRICE EN CHEF / EDITOR-IN-CHIEF : Laure Desutter-Grandcolas

AssistanTS DE RÉDACTION / AsSISTANT EDITORS: Anne Mabille (zoosyst@mnhn.fr), Emmanuel Côtez

Mise en PAge / PAgE LAYOUt: Anne Mabille

COMITÉ SCIENTIFIQUE / SCIENTIFIC BOARD:

James Carpenter (AMNH, New York, États-Unis)

Maria Marta Cigliano (Museo de La Plata, La Plata, Argentine)

Henrik Enghoff (NHMD, Copenhague, Danemark)

Rafael Marquez (CSIC, Madrid, Espagne)

Peter Ng (University of Singapore)

Gustav Peters (ZFMK, Bonn, Allemagne)

Norman I. Platnick (AMNH, New York, États-Unis)

Jean-Yves Rasplus (INRA, Montferrier-sur-Lez, France)

Jean-François Silvain (IRD, Gif-sur-Yvette, France)

Wanda M. Weiner (Polish Academy of Sciences, Cracovie, Pologne)

John Wenzel (The Ohio State University, Columbus, États-Unis)

COUVERTURE / COVER:

Trogolaphysa judithnajtae n. sp., habitus holotype.

\author{
Zoosystema est indexé dans / Zoosystema is indexed in: \\ - Science Citation Index Expanded (SciSearch $\left.{ }^{\circledR}\right)$ \\ - ISI Alerting Services ${ }^{\circledR}$ \\ - Current Contents ${ }^{\circledR}$ / Agriculture, Biology, and Environmental Sciences ${ }^{\circledR}$ \\ - Scopus ${ }^{\circledR}$
}

Zoosystema est distribué en version électronique par / Zoosystema is distributed electronically by:

- BioOne ${ }^{\circledR}$ (http://www.bioone.org)

Les articles ainsi que les nouveautés nomenclaturales publiés dans Zoosystema sont référencés par / Articles and nomenclatural novelties published in Zoosystema are referenced by:

- ZooBank ${ }^{\circledR}$ (http://zoobank.org)

Zoosystema est une revue en flux continu publiée par les Publications scientifiques du Muséum, Paris / Zoosystema is a fast track journal published by the Museum Science Press, Paris

Les Publications scientifiques du Muséum publient aussi / The Museum Science Press also publish:

Adansonia, Anthropozoologica, European Journal of Taxonomy, Geodiversitas, Naturae.

Diffusion - Publications scientifiques Muséum national d'Histoire naturelle

CP 41 - 57 rue Cuvier F-75231 Paris cedex 05 (France)

Tél. : 33 (0)14079 4805 / Fax: 33 (0)14079 3840

diff.pub@mnhn.fr / http://sciencepress.mnhn.fr

(c) Publications scientifiques du Muséum national d'Histoire naturelle, Paris, 2018

ISSN (imprimé / print): 1280-9551/ ISSN (électronique / electronic): 1638-9387

PHOTOCOPIES :

Les Publications scientifiques du Muséum adhèrent au Centre Français d'Exploitation du Droit de Copie (CFC), 20 rue des Grands Augustins, 75006

Paris. Le CFC est membre de l'International Federation of Reproduction Rights Organisations (IFRRO). Aux États-Unis d'Amérique, contacter le Copyright Clearance Center, 27 Congress Street, Salem, Massachusetts 01970.
PHOTOCOPIES:

The Publications scientifiques du Muséum adhere to the Centre Français d'Exploitation du Droit de Copie (CFC), 20 rue des Grands Augustins, 75006 Paris. The CFC is a member of International Federation of Reproduction Rights Organisations (IFRRO). In USA, contact the Copyright Clearance Center, 27 Congress Street, Salem, Massachusetts 01970. 


\title{
Annotated checklist of Afrotropical Trogolaphysa Mills, 1938 (Hexapoda: Collembola: Paronellidae) and description of a new species from Madagascar
}

\author{
Minh NGUYEN \\ School of Integrative Biology, University of Illinois, Urbana-Champaign, \\ 265 Morrill Hall, 505 S. Goodwin Ave. Urbana, IL 61801 (United States) \\ mnguye49@illinois.edu
}

Felipe N. SOTO-ADAMES

Department of Entomology, University of Illinois, Urbana-Champaign, 320 Morrill Hall, 505 S. Goodwin Ave. Urbana, IL 61801 (United States) and Department of Biology University of Puerto Rico, San Juan Puerto Rico, 00931 (United States) and Florida State Collection of Arthropods, Division of Plant Industry, Florida Department of Agriculture and Consumer Services, Gainesville, FL 32608 (United States) felipe.soto-adames@freshfromflorida.com (corresponding author)

KEY WORDS

Species identification key, chaetotaxy,

biogeography,
Gondwana, new combinations, new species.
Submitted on 16 August 2016 | Accepted on 6 February 2018 | Published on 23 May 2018

Nguyen M. \& Soto-Adames F. N. 2018. - Annotated checklist of Afrotropical Trogolaphysa Mills, 1938 (Hexapoda: Collembola: Paronellidae) and description of a new species from Madagascar. Zoosystema 40 (10): 179-196. https://doi.org/10.5252/zoosystema2018v40a10. http://zoosystema.com/40/10

\section{ABSTRACT}

The Paronellini Börner, 1906 of Africa and Madagascar are poorly known. Nineteen Paronella-like species have been reported from Africa, but it is unclear how they are distributed among genera as currently defined. Here we review all references containing descriptions and reports of Paronella-like species from Africa, Madagascar and the Seychelles. And based on that information we propose generic allocations for all forms. As a result, 11 species are referred to Trogolaphysa Mills, 1938; three to Paronella Schött, 1893; one to Troglopedetes Absolon, 1907; one may be assigned to either Trogolaphysa or Lepidonella Yosii, 1960; one could be placed in Trichorypha Schött, 1893 or Paronella, and two are nomina nuda. For all forms referred to as Trogolaphysa we provide a short list of synonymy, diagnosis, and an identification key. We also described a new species, Trogolaphysa judithnajtae n. sp., from Madagascar, which is distinguished from Trogolaphysa wahlgreni (Mitra, 2002) n. comb. by being blue instead of white, lacking labral papillae, and having two rows of spines on the dens instead of one. 


\begin{abstract}
RÉSUMÉ
Liste annotée des Trogolaphysa Mills, 1938 afrotropicale (Hexapoda: Collembola: Paronellidae), avec la description d'une nouvelle espèce de Madagascar.

Les Paronellini Börner, 1906 d'Afrique et de Madagascar sont mal connus. Dix-neuf espèces ont été signalées en Afrique, mais leur répartition dans les genres tels qu'actuellement définis n'est pas claire. Dans ce travail, nous passons en revue toutes les références bibliographiques contenant des descriptions et des citations d'espèces à morphologie de type Paronella Schött, 1893 pour l'Afrique, Madagascar et les Seychelles. Sur la base de ces informations nous proposons une assignation générique pour toutes ces formes. Onze espèces sont assignées au genre Trogolaphysa Mills, 1938 ; trois à Paronella; une pourrait être assignée soit à Trogolaphysa soit à Lepidonella Yosii, 1960; une à Troglopedetes Absolon, 1907; une pourrait être placée soit dansTrichorypha Schött, 1893 soit dans Paronella; et deux sont des nomina nuda. Pour toutes les formes assignées à Trogolaphysa, nous fournissons une liste de synonymes, une diagnose, et une clé d'identification. Nous décrivons également une nouvelle espèce, Trogolaphysa judithnajtae n. sp., de Madagascar, qui se distingue de T. wahlgreni (Mitra, 2002) n. comb. par sa coloration bleu (versus blanc), l'absence de papilles labrales, et la présence de deux rangées d'épines sur les dens (versus une seule).
\end{abstract}

\section{INTRODUCTION}

Madagascar is one of the most biologically diverse islands in the world, but little is known about the diversity of Paronellini Börner, 1906 in the area. Most studies on Malagasy paronellids have been devoted to the genus Salina MacGillivray, 1894 (Delamare Debouteville 1948, 1950a); only two species of Paronellini, Paronella fuelleborni Börner, 1903 and Cyphoderopsis madagascarensis (Wilson, 1982), have been reported from the island (Womersley 1934; Wilson 1982). Recently we received a vast collection of springtails from Madagascar, obtained as part of ongoing efforts by members of the California Academy of Science to describe and understand the invertebrate fauna of the island. Most samples contain vegetation-climbing springtails and are particularly rich in members of genera Seira Lubbock, 1869 and Salina, but some samples also include edaphic and epiedaphic forms. Among the samples of epidaphic springtails collected across the island we detected a Paronella-like species, and saw the opportunity to contribute to clarifying the status of the only member of the genus reported from the island, the poorly characterized $P$. fuelleborni.

Recent taxonomic revisions and advances in our understanding of the morphology of Paronella-like species have stimulated analysis of species diversity in the genus Trogolaphysa Mills, 1938. Most of the recent descriptive and revisionary work has concentrated on the Neotropical fauna, which now includes 51 named species (Soto-Adames \& Taylor 2013; Soto-Adames et al. 2014, Soto-Adames \& Bellini 2015; da Silva \& Bellini 2015). Study of Afrotropical Paronella-like species, on the other hand, has languished to the point that it is unclear how many of the forms reported for this region belong in Trogolaphysa.

Among the Paronella-like forms described from Africa and surrounding islands (including Madagascar and the Seychelles), 17 named species may belong in Trogolaphysa
(Mitra 2002c; Thibaud 2013; Zon et al. 2013)(Table 1). Most Paronella-like species were reported before the 1970's and their descriptions and diagnoses relied mostly on color pattern, characters of the claw complex, shape of mucro and a few other morphological characters. Only the most recently described species, Dicranocentruga wahlgreni Mitra, 2002, and to a lesser extent Lepidonella flava (Carpenter, 1916), T. vivieni (Barra, 1969) and T. monomaculata (Barra, 1969) have been described in sufficient detail to allow comparison of some aspects of the chaetotaxy. To facilitate future studies of African Paronellini, we present an annotated checklist of African species that could belong to Trogolaphysa; we also include an identification key and describe a new species based on the material from Madagascar.

\section{MATERIAL AND METHODS}

Specimens were cleared in Nesbitt's solution, double mounted in Mark Andre II on glass slides (Mari Mutt 1979; Christiansen \& Bellinger 1998) and studied under a phase contrast compound microscope. Figures were drawn using a drawing tube, and final illustrations were prepared using Microsoft PowerPoint 2010 and Adobe Illustrator CC v21.0.

Nomenclature of head and body macrochaetae follows Soto-Adames (2015). Body macrochaetae formula refers to mesothorax, metathorax/abdomen 1-3, abdomen 4 columns $\mathrm{A}+\mathrm{B}, \mathrm{C}, \mathrm{D}+\mathrm{E}+\mathrm{F}$. In the figures, open circles represent macrochaetae; dots are microchaetae; open circles with cross line are pseudopores; wiggly lines are bothriotricha.

The holotype and most paratypes are deposited in the collection of the California Academy of Sciences (CAS); representative paratypes, as listed in Type material, from each locality are kept at the Florida State Collection of Arthropods (FSCA), Gainesville, Florida, USA and the Muséum national d'Histoire naturelle, France (MNHN). 


\section{SYSTEMATICS}

Family PARONELLIDAE Börner, 1906

Subfamily PARONELLINAE Börner, 1906

sensu Soto-Adames et al. (2008)

Tribe PARONELLINI Börner, 1906

sensu Soto-Adames et al. (2014)

\section{Genus Trogolaphysa Mills, 1938 \\ sensu Soto-Adames (2015)}

\section{Trogolaphysa Mills, 1938: 184.}

TYPE SPECIES. - Trogolaphysa maya Mills, 1938: 184, by original designation.

TYPE LOCALITY. — Yucatan, Mexico.

DiAgnOsis. - Hyaline denticulated scales covering Ant. 1-2 head, body, and ventral face of furcula; $4^{\text {th }}$ antennal segment not subdivided; eyes 0-8; head microchaeta $\mathrm{Ps}_{3}$ absent; labial chaetae L1 and L2 subequal; inner dorsal chaetotaxy of metathorax and $1^{\text {st }}$ abdominal segment reduced to 4 and 3 chaetae, respectively; abdominal segments 2-4 with 2, 3, 3 bothriotricha; manubrium without spines; dens with 1-2 rows of spines; mucro square or rectangular but relatively short, with 3-5 teeth.

\section{REMARKS}

Published descriptions of species listed below as belonging to Trogolaphysa (except for D. wahlgreni and the new species) do not refer to most characters listed in the diagnosis of the genus. For this study, we assign to Trogolaphysa all forms originally placed in the genus Paronella Schött, 1893 that, based on available descriptions, have a square or short rectangular mucro bearing 3-5 teeth, and lack manubrial spines and a subdivision on the $4^{\text {th }}$ antennomere. This limited combination of characters is not unique to Trogolaphysa, as it would also fit some members of the genus Lepidonella Yosii, 1960. Trogolaphysa and Lepidonella are easily distinguished based on chaetotaxy, and to a large extent, on mucro shape. Most species of Trogolaphysa (at least the Neotropical forms) have the typical relatively short (or even shorter) mucro shown in Fig. 3C, whereas in Lepidonella (and more so in Troglopedetes Absolon, 1907/Cyphoderopsis Carpenter, 1917) the mucro tends to be appreciably longer. A few species of Lepidonella do have short mucrones, but most of these are shaped very differently from those in Trogolaphysa (Fig. 3C; Soto-Adames \& Bellini 2015: figs 28, 29). Only Lepidonella ceylonica (Yoshi, 1966), and L. nigrofasciata (Handschin, 1928) have Trogolaphysa-like short mucrones, and both species are found in South Asia. Lepidonella has never been reported from the African mainland; only L. flava (Carpenter, 1916; from the Seychelles) has been reported from a region near Africa. The chaetotaxy of most species listed below is not known but the mucro is always illustrated. Although we use mucro shape as the main character to assign species to Trogolaphysa, other characters, when available, are used in support of our determination. Thus, the description of Lepidonella flava is not sufficiently detailed to assigned it to Lepidonella or Trogolaphysa, but we have retained it in Lepidonella based on one aspect of the chaetotaxy. We present our comments on L. flava following the identification key to African Trogolaphysa. Trogolaphysa vivieni (Barra, 1969) and T. monomaculata have distinctive mucrones (especially T. viviani), which are atypical for the genus, but Soto-Adames \& Bellini (2015) transferred them to Trogolaphysa on account of the number of bothriotricha on the $4^{\text {th }}$ abdominal segment and absence of head chaeta $\mathrm{Ps}_{3}$. Justification for placing other species in Trogolaphysa is given in the 'Remarks' to each form.

\section{ANNOTATED CHECKLIST OF AFRICAN TROGOLAPHYSA}

Thibaud's (2013) report on African springtails lists 17 species and three subspecies in the genera Paronella, Microparonella Carpenter, 1916 and Trichorypha Schött, 1893 that may belong in Trogolaphysa (Table 1). We evaluated published descriptions of the species listed in Thibaud (2013) in light of current generic delimitation and the distinguishing criteria listed above, and our conclusions are presented below (Table 1).

Following Deharveng \& Bedos (1995) Microparonella caerulea Carpenter, 1916 belongs in Troglopedetes. Mitra (2002a) studied a syntype of M. caerulea Carpenter, 1916 and suggested that Microparonella was a valid genus. However, the specimen Mitra examined was missing the three distal antennal segments and he could not be aware of the diagnostic character placing the species in Troglopedetes (see Remarks below under L. flava).

Paronella villiersi Delamare Debouteville \& Pauliani, 1947 has been cited close to 10 times in the last 65 years, but the species was never described or illustrated and therefore the combination is a nomen nudum. Paronella penicillata obscura Delamare Debouteville, 1951, from Ivory Coast was never diagnosed and is also a nomen nudum.

Paronella eburnea Delamare Debouteville \& Paulian, 1947 is a nomen nudum, which may have referred to a species from Ivory Coast later described as Aphysa eburnea Delamare Debouteville, 1951. The shape of the mucro and length of antennae suggest that $A$. eburnea belongs in Callyntrura Börner, 1906 or at least in Callyntrurini Mitra, 1993.

The generic status of Paronella atrofasciata (Schött, 1893) is unclear. Thibaud \& Najt (1988) indicated that type material of $P$. atrofasciata they examined fit the diagnosis of Paronella in having $6+6$ eyes, relatively short antennae and manubrial spines. However, Mitra (2002b) reported syntypes as having $8+8$ eyes, antennae longer than body and manubrial spines absent. The absence of manubrial spines excludes the specimens Mitra examined from Paronella. The additional absence of extra-ocular structure (eos) in combination with other characters lead Mitra to resurrect the genus Trichorypha. The chaetotaxy for Abd. 2-4 illustrated by Mitra (2002b) for T. atrofasciata is unlike that seen in other Paronellini. A clarification of the status of this species will require examination of the chaetotaxy of the complete type series or fresh material from Cameroon.

Paronella fusca Schött, 1893 (Type species of Paronella), P. montana Delamare Debouteville, 1952 and P. purpurea Barra, 1969 carry manubrial spines and belong to Paronella s. str. (Thibaud \& Najt 1988). 
TABLE 1. - Generic status of African Paronella-like species.

\begin{tabular}{|c|c|c|c|}
\hline Species & $\begin{array}{l}\text { Original Generic } \\
\text { placement }\end{array}$ & Current Generic placement & Distribution \\
\hline atrofasciata Schött, 1893 & Tricorhypha & $\begin{array}{l}\text { Trichorypha? (Mitra 2002a) } \\
\text { Paronella? (Thibaud \& Najt 1988) }\end{array}$ & Cameroon \\
\hline beguei Delamare Debouteville, 1951 & Paronella & Trogolaphysa (present study) & Ivory Coast \\
\hline caerulea Carpenter, 1916 & Microparonella & Troglopedetes (Deharveng \& Bedos 1995) & Seychelles \\
\hline $\begin{array}{l}\text { eburnea Delamare Debouteville \& } \\
\text { Pauliani, } 1947\end{array}$ & Paronella (see discussion) & Callyntrura? (several authors) & Ivory Coast \\
\hline flava Carpenter, 1916 & Microparonella & Lepidonella (Deharveng \& Bedos 1995) & Seychelles \\
\hline fuellerboni Börner, 1903 & Paronella & Trogolaphysa (present study) & $\begin{array}{l}\text { Tanzania } \\
\text { Madagascar? }\end{array}$ \\
\hline fusca Schött, 1893 & Paronella & Paronella (Schött 1893) & Cameroon \\
\hline ghesquieri Marlier, 1945 & Paronella & Trogolaphysa (present study) & Republic of Congo \\
\hline grassei Delamare Debouteville, 1952 & Paronella & Trogolaphysa (present study) & Ivory Coast \\
\hline lamottei Delamare Debouteville, 1950 & Paronella & Trogolaphysa (present study) & Guinea \\
\hline judithnaitae n. sp. & Trogolaphysa & Trogolaphysa (present study) & Madagascar \\
\hline monomaculata Barra, 1969 & Paronella (Microparonella) & Trogolaphysa (Soto-Adames \& Bellini 2015) & Gabon \\
\hline montana Delamare Debouteville, 1950 & Paronella & Paronella (Barra 1969) & Ivory Coast \\
\hline nigromaculata Schött, 1903 & Paronella & Trogolaphysa (present study) & $\begin{array}{l}\text { Cameroon, Ivory Coast, } \\
\text { Rwanda, Burundi, Tanzania, } \\
\text { Ethiopia, South Africa }\end{array}$ \\
\hline penicilata Schött, 1927 & Paronella & Trogolaphysa (present study) & $\begin{array}{l}\text { Cameroon, Ivory Coast, } \\
\text { Gabon }\end{array}$ \\
\hline purpurea Barra, 1969 & Paronella & Paronella (Barra 1969) & Gabon \\
\hline villersi Delamare Debouteville, 1951 & Paronella & nomen nudum & - \\
\hline viviani Barra, 1969 & Paronella (Microparonella) & Trogolaphysa (Soto-Adames \& Bellini 2015) & Gabon \\
\hline wahlgreni Mitra, 2002b & Dicranocentruga & Trogolaphysa (present study) & Kenya \\
\hline
\end{tabular}

The remaining 12 species of Paronella reported from Africa may be tentatively assigned to Trogolaphysa. The annotated checklist and identification key presented below are based on our evaluation of published descriptions and records. In the annotations we discuss some important papers concerning the taxonomy of each species, but it was not our intention to list all citations for all species. Synonymies, complete up to around 2000, for all forms are available from www.collembola.org (Bellinger et al. 1996-2018) under links to 'Publications' and 'Collembola species catalogue'

\section{Trogolaphysa beguei}

(Delamare Debouteville, 1951) n. comb.

Paronella beguei Delamare Debouteville 1951a: 1074, figs 5-12 (Ivory Coast); 1951b: 60, 82, 135, 166, 176, 254, 266, fig. 21 (ecology, Ivory Coast).

Paronella beguei - Delamare Debouteville 1948: 309, 376, 421, nomen nudum.

Dicranocentruga beguei - Mitra 2002c: 114.

TyPe Locality. — Le Banco, Ivory Coast.

Distribution. — Ivory Coast.

\section{REMARKS}

Delamare Debouteville first used the combination Paronella beguei in 1948 referring to a paronellid found together with termites. This first mention of $P$. beguei included neither a morphological description nor drawings and therefore it is a nomen nudum.

The only other significant citations for $P$. beguei are those of Delamare Debouteville (1951b), concerning its ecology, and Mitra (2002c) in which the author transfers the species to the genus Dicranocentruga Wray, 1953.

We assign this species to Trogolaphysa based on mucro shape, which is typical for the genus, short and bearing 4 teeth, and the relatively long antennae. Otherwise, this is a well-marked species, unique among African forms in having a distinctive color pattern (Fig. 5J) and truncate unguiculus (Fig. $5 \mathrm{H}$ ).

Trogolaphysa fuelleborni (Börner, 1903) n. comb.

Paronella fuelleborni Börner, 1903: 143-144, fig. 10 (Langenburg, Nyassa region, Tanzania). - Wahlgren, 1908 (compared to P. nigromaculata, description of color pattern and claw structure, Kilimanjaro, Tanzania). — Philiptschenko 1926: 192-193 (proposed as synonym of $P$. nigromaculata Schött, 1903). - Denis 1933: 263, 268 (compared to T. separata Denis, 1933, suggestion that synonymization with $P$. nigromaculata by Philiptschenko [1926] is unjustified). - Womersley 1934: 441, 471 (records from literature?, Tanzania [Nyassa, Kilimanjaro], Madagascar?). — Martynova 1961: 482-483 (synonym of $P$. nigromaculata).

Dicranocentruga fuelleborni - Mitra 2002c: 114.

TyPe LOCALITY. - Langenburg (now Tukuyu), Nyassa region, Tanzania.

Distribution. - Tanzania (Tukuyu, Kilimanjaro), Madagascar? 


\section{REMARKS}

This species was originally described from southern Tanzania, near the northern shore of Lake Malawi. Börner's (1903) original description dealt mostly with generalized characters that provide little valuable information to characterize the species. This has resulted in general confusion on the identity of the species, and whether it is a junior synonym of $P$. nigromaculata Schött, 1903. Thus, on examining specimens from Kenya he identified as P. nigromaculata, Philiptschenko (1926) declared the species to be so variable as to encompass the morphology observed in T. fuelleborni n. comb. Denis (1933) included T. fuelleborni n. comb. in his key to Paronella species and pointed out that the placement of inner teeth of the unguis (on the distal half of the inner margin) distinguishes this species from $P$. nigromaculata. Denis further suggested that Philiptschenko's material from Kenya may represent a different species altogether. Womersley (1934) published a list of African species which included a report of T. fuelleborni n. comb. from Madagascar. Womersley (1934) did not provide additional information about the material on which this report was based, and it remains unclear if the report from Madagascar is real or a mistake. Martynova (1961) supported Philiptschenko's conclusion based on the variation displayed by material from Kenya she identified as P. nigromaculata.

We place this species in Trogolaphysa based on its general similarity to $P$. nigromaculata (see Remarks to $P$. nigromaculata below). Given the confusion in the literature as to how to characterize T. fuelleborni n. comb., it is difficult to provide an adequate description without examining type specimens or topotypical material. Following Börner's (1903) original description the species has a light brownish yellow background color with dark blue pigment covering flanks of body, head darker anteriorly, $1^{\text {st }}$ and $2^{\text {nd }}$ antennal segments light, all other antennal segments dark blue, coxae dark blue; tenet hair long and spatulate; unguis with 4 inner teeth, paired teeth subequal, inserted on distal half of inner edge, proximal unpaired tooth shorter than paired teeth and inserted on distal half of inner edge, away from basal teeth; dens with 1 row of spines; mucro short, with 4 teeth.

Based on the descriptions available, the only character distinguishing T. fuelleborni n. comb. is the displacement of the inner teeth of the unguis to the distal half of the claw (Fig. 5C).

\section{Trogolaphysa ghesquierei (Marlier, 1945) n. comb.}

Paronella ghesquierei Marlier, 1945: 260, 261, fig. 6 (Eala, Belgian Congo).

Dicranocentruga ghesourieri - Mitra 2002c: 114; lapsus calami.

Type LOCAlity. - Eala, Democratic Republic of Congo.

Distribution. - Democratic Republic of Congo.

\section{REMARKS}

The only citations for this form are the original description, and its transfer to Dicranocentruga by Mitra (2002c). The species remains poorly characterized, but the shape of the mucro and absence of manubrial spines suggest it should be placed in Trogolaphysa. The Congolese species was described as uniformly yellow, with brown legs; a long spatulate tenent hair; unguis with four inner teeth; lanceolate unguiculus; dens with one row of spines; and four-toothed mucro.

Among African Trogolaphysa, this appears to be the only uniformly yellow species with four inner ungual teeth and paired teeth inserted on the basal half of the claw.

\section{Trogolaphysa grassei}

(Delamare Debouteville, 1952) n. comb.

Paronella grassei Delamare Debouteville, 1952: 241, 242, figs 4-7 (Le Banco, Ivory Coast).

Paronella grassei Delamare Debouteville - 1951b: 63, fig. 16, nomen nudum.

Dicranocentruga grassei - Mitra 2002c: 114.

Type locality. — Le Banco, Ivory Coast.

Distribution. — Ivory Coast.

\section{REMARKS}

Delamare Debouteville (1951b) first published a plate showing diagnostic characters for this species and included the combination Paronella sp. in the caption to the figure. However, this publication did not include a description of the species. Delamare Debouteville (1952) published the 1951b plate and caption again, but this time he included a formal description. Following the ICZN code, the absence of a description and diagnosis renders the $1951 \mathrm{~b}$ combination a nomen nudum and the correct authority citation is $P$. grassei Delamare Debouteville, 1952 .

This species is placed in Trogolaphysa based on the absence of manubrial spines and on the shape of the mucro, which is typical for Trogolaphysa species with 3-teethed mucro.

This species has a white head and light blue pigment on legs and body flanks; tenent hair relatively short and weakly spatulate (Fig. 5A); unguis with three inner teeth; unguiculus lanceolate; dens with two rows of spines; and mucro with 3 teeth.

This is the only African species with a three-toothed mucro.

\section{Trogolaphysa lamottei}

(Delamare Debouteville, 1950) n. comb.

Paronella lamottei Delamare Debouteville, 1950b: 43-44, figs 1-6 (Mt Nimba, Guinea).

Dicranocentruga lamottei - Mitra 2002c: 114.

Type locality. - Mt Nimba, Guinea.

Distribution. - Guinea. 


\section{REMARKS}

This species has not been reported again since the original description. The only additional relevant citation is that by Mitra (2002c), in which he transferred it to the genus Dicranocentruga.

Paronella lamottei is placed in Trogolaphysa based on the shape of the mucro and absence of manubrial spines. However, this species approaches Paronella/Trychorypha atrofasciata in the presence of relatively long antennae and in having the manubrium distinctly longer than the dens, and it ultimately may belong to that species/genus group.

Paronella lamottei is characterized by a long and thin body, with relatively long antennae, which is common in cave forms but atypical for surface Trogolaphysa; body white, except for lateral margins of the mesothorax to the 1 st abdominal segment and tibiotarsi; $1^{\text {st }}$ antennal segment white, but all other segments dark blue; tenet hair relatively long and strongly spatulate; unguis with 4 inner teeth; unguiculus lanceolate; dens with two rows of spines; and mucro with 4 teeth.

This species should be easy to recognize by its general habitus and color pattern (Fig. 5I).

\section{Trogolaphysa judithnajtae n. sp.} (Figs 1-3)

\section{urn:Isid:zoobank.org:act:16B525F2-9F21-4A3C-A6C7-F85DCDF23BFF}

Type Material. - Holotype. 9 , slide-mounted, Madagascar, Province d'Antsiranana, Nosy Be Réserve naturelle intégrale de Lokobe. $6.3 \mathrm{~km}$ ESE Hellville, 19-24.III.2001, 1325'10”S, 48¹9'52”E, pitfall trap in rainforests, B. L. Fisher, Griswold et al., CAS, coll. code BLF3418, CASLOT 041427.

Paratypes. All deposited at CAS, unless otherwise specified. 4 in preparation (2 MNHN, 2 FSCA) and 8 (2 MNHN, 2 FSCA) in alcohol with same collection information as holotype; 5 slide mounted (1 MNHN, 1 FSCA) and 8 individuals in alcohol, Toliara Prov. Reserve Price Berenty, forêt de Bealoka, Mandraré River, $14.6 \mathrm{~km} 329^{\circ} \mathrm{NNW}$ Amboasary, Elev. 35 m, 3-8.II.2002, 2457'25”S, 46¹6'17”E, B. L. Fisher, Griswold et al., pitfall trap in gallery forest, Coll. code BLF5314, CASLOT 041; 5 slide mounted and up to 100 in alcohol, Toliara Prov. Reserve Price Berenty, forêt de Bealoka, Mandrake River, $14.6 \mathrm{~km} 329^{\circ} \mathrm{NNW}$

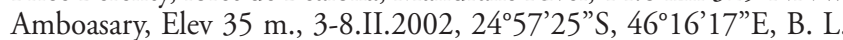
Fisher, Griswold et al. pitfall trap in Gallery Forest, code BLF3314, CASLOT 044128; 4 slide mounted and 16 in alcohol (2 FSCA),

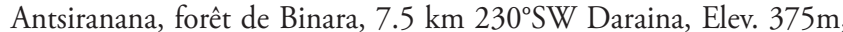
1.XII. $2003,13^{\circ} 15^{\prime} 18^{\prime \prime} S, 049^{\circ} 37^{\prime} 00^{\prime \prime} \mathrm{E}, \mathrm{B}$. L. Fisher, pitfall trap, tropical dry forest, code BLF9558, CASLOT 041408; 5 slide mounted (1 FSCA) and 10 in alcohol, Mahajanga, Prov, Parc National Tsingy de Bemaraha, $10.6 \mathrm{~km}$ ESE $123^{\circ}$ Antsalova, Elev. $150 \mathrm{~m}, 16-20 . X I .2001$,

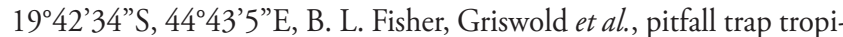
cal dry forest on Tsingy, Coll. code BLF4433, CASLOT 04196; 5 slide mounted (1 FSCA) and 210 in alcohol (10 FSCA), Mahajanga Prov,

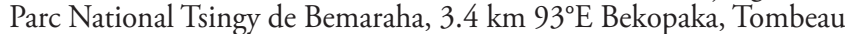
Vazimba, Elev. 50m, 6-10.XI.2001, 198'31'S, 4449’41”E, B. L. Fisher, Griswold et al., pitfall trap in tropical dry forest, Coll. code BLF4230, CASLOT 041849; 3 slide mounted and 3 in alcohol, Toamansina Parcelle E3 Tampolo, Elev. 10 m, 14.IV.2004, 17¹7'00”S, 049²6’00"E, coll.: Malagasy ant team, yellow pan trap, littoral forest, Coll. code BLF10730, CASLOT 038816; 2 slide mounted and 350 in alcohol (10 FSCA), Province de Mahajanga, Parc national d'Ankarafantsika, forêt de Tsimaloto, $18.3 \mathrm{~km} 46^{\circ} \mathrm{NE}$ de Tsaramandroso, Elev. $135 \mathrm{~m}, 2-8$. IV.2001, 16 $13^{\prime} 41^{\prime \prime}$ S, 46 $6^{\circ} 37^{\prime \prime}$ E, B. L. Fisher, Griswold et al., pitfall trap in tropical dry forest, Coll. code BLF3597, CASLOT 044347; 4 slide mounted ( 1 slide FSCA) and 2 in alcohol, Toliara Prov., forêt de Mite,

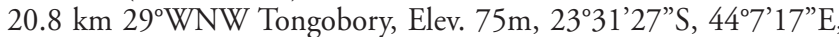
27.II.-3.III.2002, B. L. Fisher, Griswold et al., pitfall trap in gallery forest, Coll. code BLF5848, CASLOT 041967.

Distribution. - Madagascar (Fig. 4).

ETymology. - The epithet honors Judith Najt, for her contributions to our understanding of the taxonomy of Paronellini.

DiAgNosis. - Trogolaphysa judithnajtae n. sp. is the only blue species with six paired anterior head macrochaetae in the combination A2, A3, A5, M2, S3 and S5 that also has four inner macrochaetae on $4^{\text {th }}$ abdominal segment $(A 3$, A5, B4, B5) and labrum lacking distal margin denticles.

\section{DESCRIPTION}

Size

Adults 2.3-2.6 mm long.

\section{Color pattern}

Background color in alcohol preserved individuals beige with blue pigment on all antennal and leg segments, manubrium, and base of collophore; interantennal field on head as dark as antennae; head light brown or uniformly blue, body mostly blue, eye patch black, anterior margin of Abd. 4 with unpigmented areas forming longitudinal streaks (Fig. 1).

\section{Scale distribution}

Present dorsally and ventrally on $1^{\text {st }}$ and 2 nd antennal segments but on $3^{\text {rd }}$ antennal segment limited to basal $1 / 4$ of dorsal face; dorsally and ventrally on head; dorsally on body; ventrally on furcula; absent from legs and collophore.

\section{Head}

Antennae up to $2.7 \times$ head length. Subapical sense organ of $4^{\text {th }}$ antennal segment a short rod contained in circular depression, guard sensillum rela tively short. Sense organ of $3^{\text {rd }}$ antennal segment with 2 main sensilla diamond shaped and inserted in a shallow depression. Eyes $8+8$, usually appearing as $6+6$, with eyes $\mathrm{H}$ and $\mathrm{G}$ reduced as typical for genus, clearly visible in few individuals; eye valley usually with 6 (5-7) ciliate chaetae (Fig. 2B). Head with 6 (5.7) anterior paired macrochaetae (A2, A3, A5, M2, S3, S5), macrochaeta S4 sometimes present (arrow in Fig. 2A), single individual with 5 macrochaetae lacks M2 and S4; macrochaeta An3p1i present; paired posterior macrochaetae Pa5 and Pm3 present. Pre-labral chaetae ciliate, all labral chaetae smooth. Distal margin of labrum smooth, without denticles. Outer maxillary lobe with basal chaeta and apical appendage smooth and subequal; sublobular plate with 2 appendages. Labial triangle formula as M1M2rEL1L2A1-5 (Fig. 2C); r acuminate, smooth, shortest of posterior chaetae; all other posterior chaetae ciliate, L2 subequal to L1. Postlabial field with $4+4$ chaetae along cephalic groove, 1 chaeta in column $\mathrm{C}$, and 5-6 chaetae between columns $\mathrm{C}$ and $\mathrm{O}$.

\section{Body}

Body macrochaetae formula 6(5-7)0/0244 + 0 +6. Mesothorax (Fig. 2D), with 1 anterior (a5) and 6 (5-7) posterior (p3 com- 


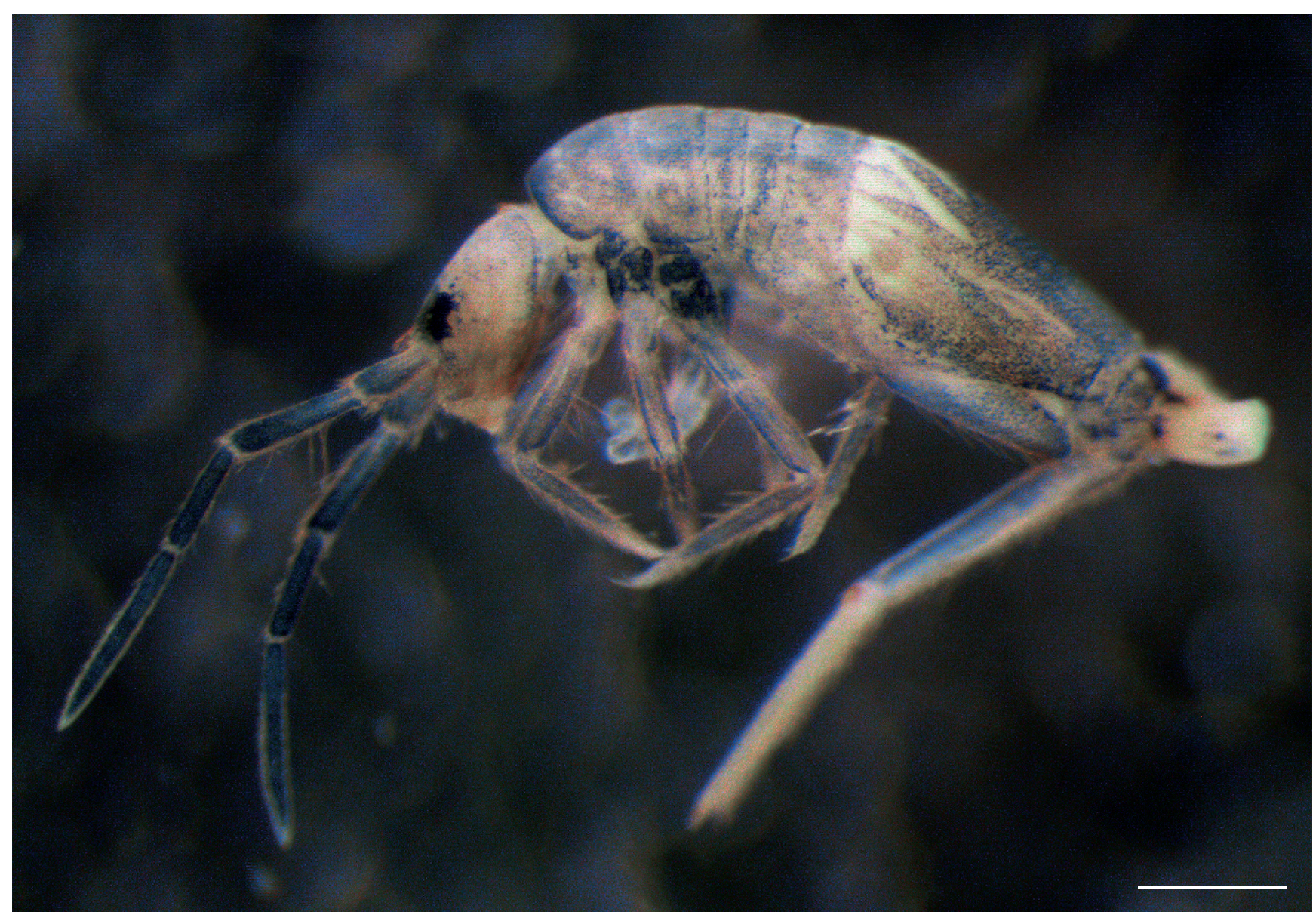

FIG. 1. - Trogolaphysa judithnajtae n. sp., habitus holotype. Scale bar: $0.5 \mathrm{~mm}$.

plex) macrochaetae. Metathorax with 4 inner microchaetae, without macrochaetae. Abdominal segment 1 with 3 inner microchaetae, chaeta a6 absent. Abdominal segment 4 (Fig. 2E) with pseudopore inserted in field posterior to T4; inner macrochaetae A3, A5, B4 and B5 present; A3 well anterior to T2; A5 inserted posterior to pseudopore; B4 inserted closer to A5 than to B5; 6 large lateral macrochaetae usually present, sometimes additional lateral macrochaetae present (Fig. 2F). Abdominal segment 4 with $10+10$ posterior chaetae; posterior intersegmental membrane with up to $6+6$ lenticular organs as described by Jantarit et al. (2013) for Cyphoderopsis.

\section{Legs}

Trochanteral organ with up to 39 chaetae. Metathoracic claw complex as in Fig. 3A, B, tenent hair spatulate on all legs, sometimes weakly so, $1.64 \times(\mathrm{n}=10)$ as long as unguiculus; claws usually with 3 (Fig. 3A), sometimes with 4 inner teeth (Fig. 3B), basal teeth subequal or one slightly longer; proximal unpaired tooth shorter than basal teeth; distal unpaired tooth inconspicuous; inner teeth spread for individuals with 3 teeth as $46 \%, 46 \%, 73 \%$, for individuals with 4 teeth as $42 \%, 42 \%, 72 \%, 90 \%$. Dorsal and lateral teeth ending on basal quarter of unguis, lateral teeth well developed. Unguiculus lanceolate, posterior edge smooth.

\section{Collophore}

Anterior face with $3+3$ inner distal macrochaetae. Lateral chaetae up to $14+14$, with 4 distal chaetae smooth and sharply tapered. Posterior face distally with many ciliate chaetae.

\section{Furcula}

Dens with 2 rows of ciliated spine-like chaetae: inner row with up to 28 spines, outer row with up 18 spines. Mucro with 4 teeth, basal teeth subpaired (Fig. 3C), one individual with basal teeth grouped on one side (Fig. 3D); mucro subrectangular, 1.6-1.9 $\times$ as long as width of distal end of dens and $0.79 \times$ as long as inner margin of metathoracic unguis.

\section{REMARKS}

The new species is most similar to T. wahlgreni n. comb. from which it can be distinguished by color pattern, absence of labral denticles, and number of rows of spines on dens as detailed in Table 2. The morphology of the new species overlaps some of the extensive morphological variation reported for T. nigromaculata $\mathrm{n}$. comb. (see below). Nevertheless, Mitra (2002c) points out that T. nigromaculata $n$. comb. lacks dorsal head macrochaetae $\mathrm{A} 3$ and $\mathrm{Pa} 5$, which are present in the new species. The few characters described for T. ghesquierei n. comb. make it almost indistinguishable from the new spe- 


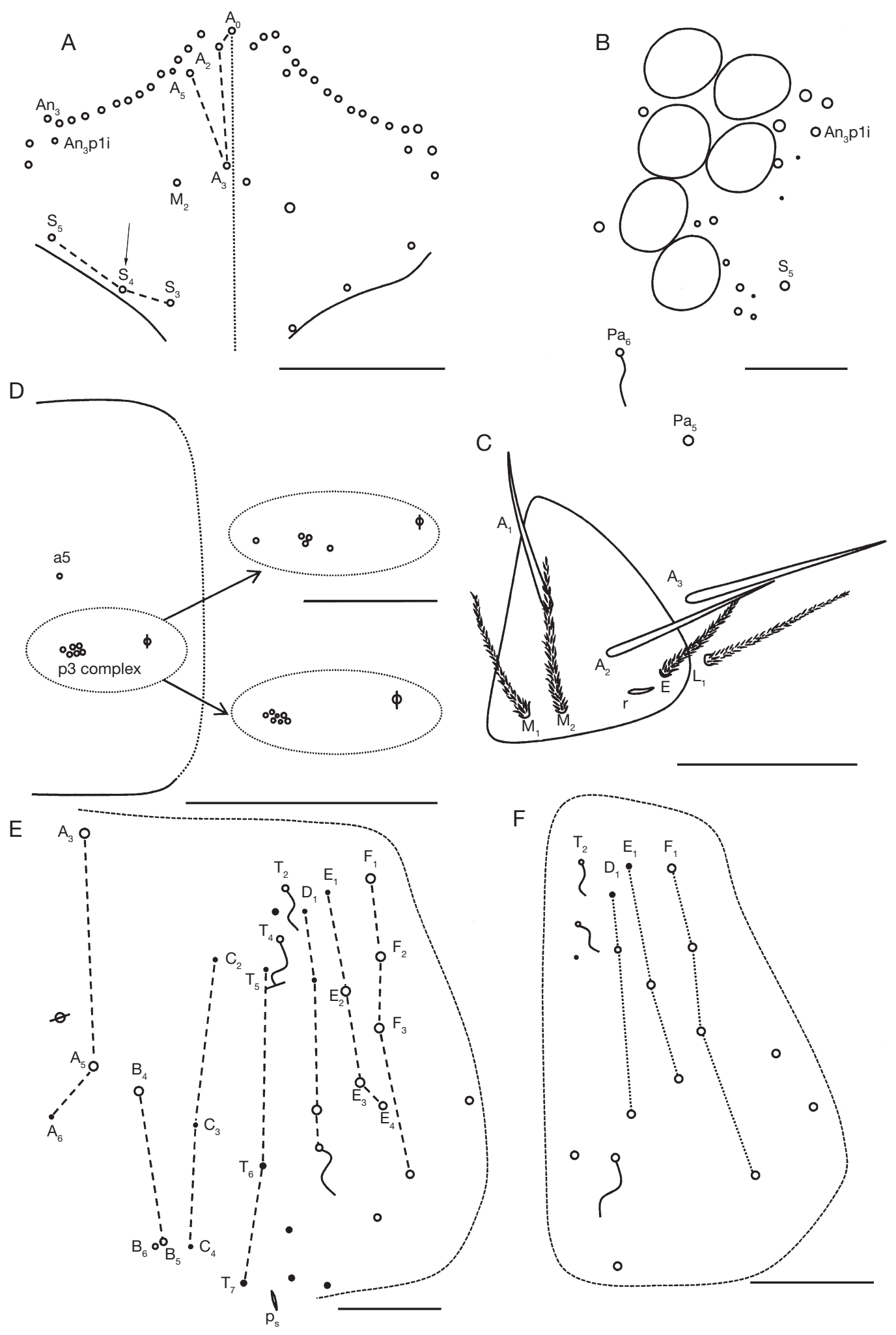

FIG. 2. - Trogolaphysa judithnajtae n. sp.: A, dorsal chaetotaxy of head, arrow points at macrochaeta that may be present or absent; B, eye patch detail; C, labial triangle; D, dorsal chaetotaxy of mesothorax, insets show variation in p3 complex; $\mathbf{E}$, dorsal chaetotaxy of abdomen 4; $\mathbf{F}$, latero-dorsal chaetotaxy of abdomen 4 in a different individual. Scale bars: A, D-F, $0.1 \mathrm{~mm}$; B, $0.05 \mathrm{~mm}$; C, $0.03 \mathrm{~mm}$. 

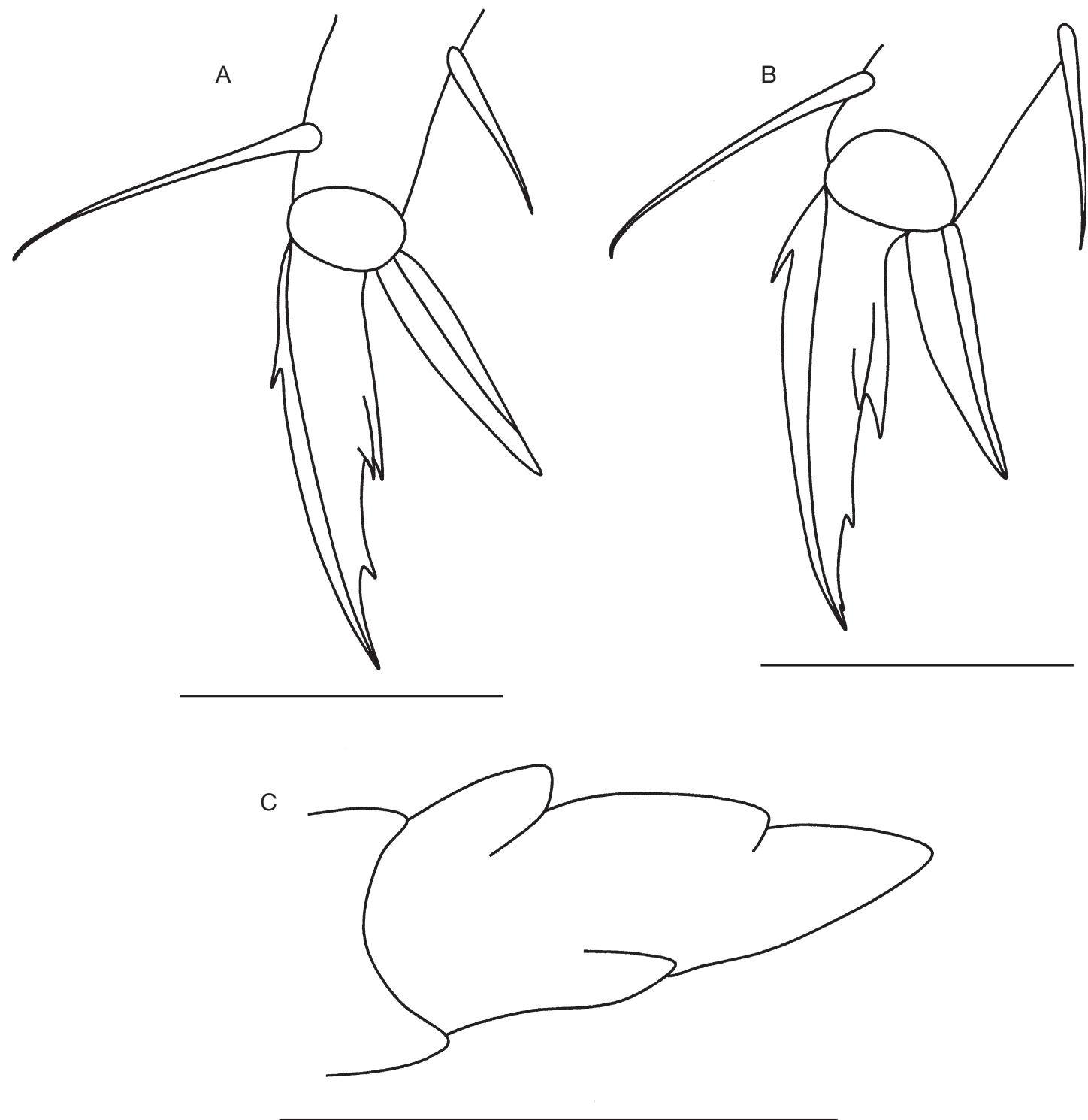

$\mathrm{D}$

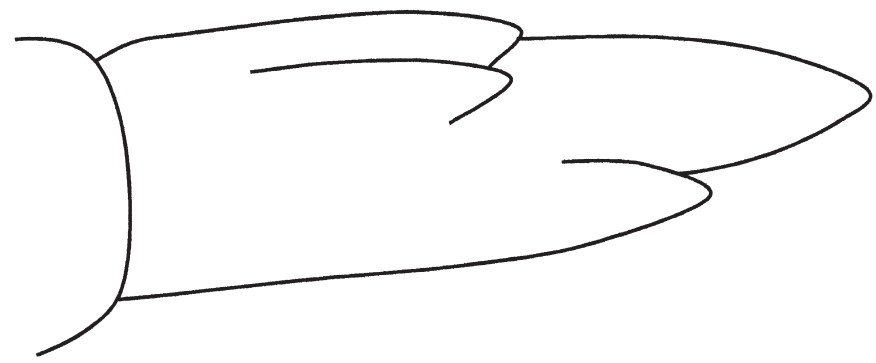

FIG. 3. - Trogolaphysa judithnajtae n. sp.: A, adult hind claw complex with three inner teeth, pretarsal setae normal, present on both sides, but not illustrated; B, adult hind claw complex with four inner teeth; C, normal adult mucro; $\mathbf{D}$, variant adult mucro. Scale bars: $0.05 \mathrm{~mm}$. 


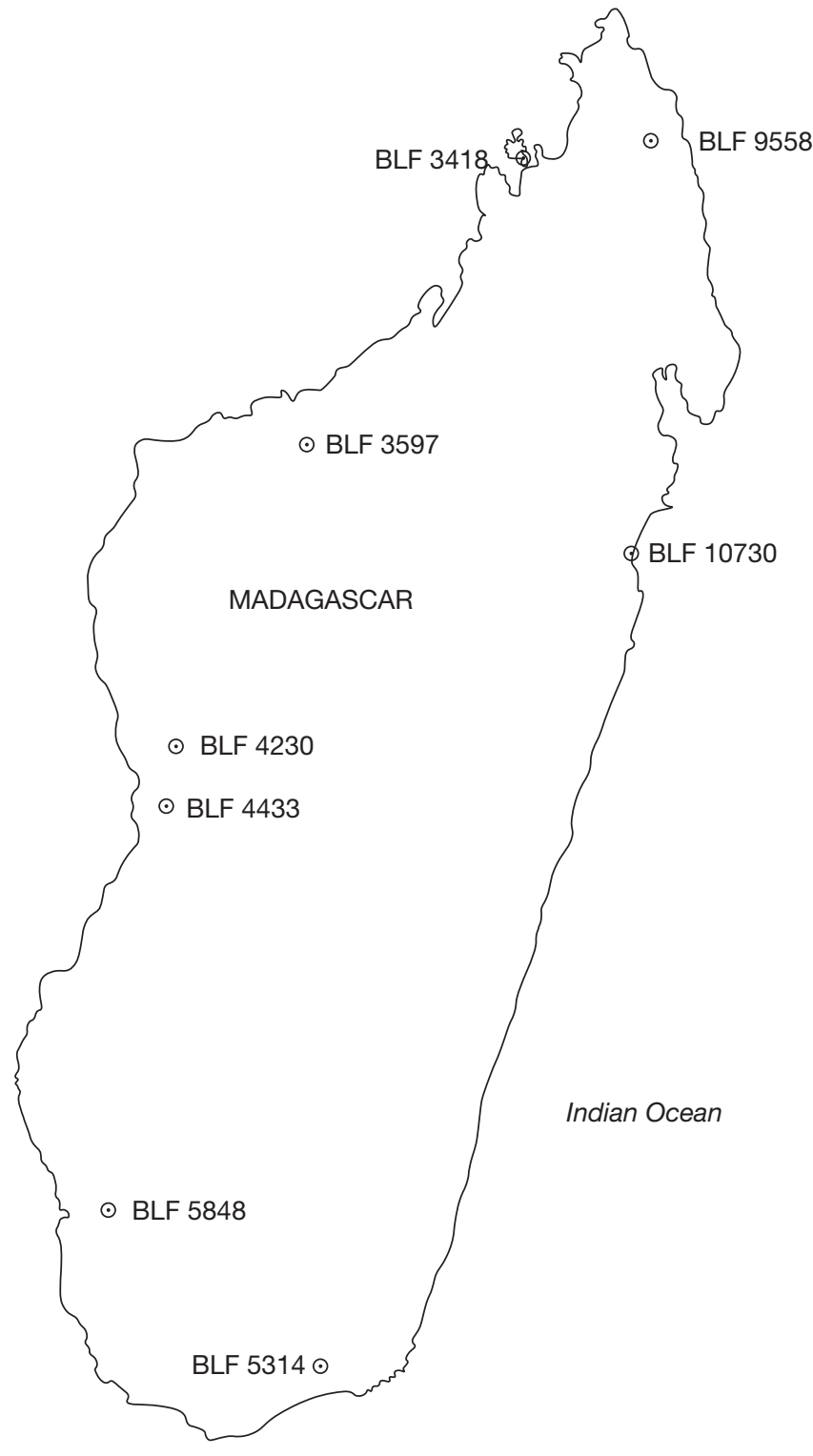

FIG. 4. - Distribution of collections of Trogolaphysa judithnajtae n. sp. in Madagascar.

cies, only the yellow body and brown legs in T. ghesquierei n. comb. separate the two forms.

Womersley (1934) reported T. fuelleborni n. comb. from Madagascar, but none of the specimens we examined from across the island has the paired ungual teeth inserted on the distal half of the inner edge, as illustrated by Börner (1903). Based on Börner's original drawing the spread of inner teeth in T. fuelleborni n. comb. is 56:56:80:90, whereas in the four-toothed form of T. judithnajtae n. sp. it is $42: 42: 72: 90$

The material examined includes populations from throughout the island, from Nosy Be and the forêt de Binara in the North to the forêt de Bealoka in Toliara Province in the Southeast (Fig. 4). At first, the variation on some important diagnostic character (number of dorsal head macrochaetae, number of macrochaetae in the p3 complex of the meso- thorax, claw dentition) lead us to think we were dealing with more than one species. We evaluated the distribution of characters among individuals and localities but did not find a correlation between them. The individuals with head macrochaeta S4 (i.e., seven paired anterior macrochaetae) or lacking macrochaeta A2 (five paired anterior macrochaetae) all come from the same population, bear three inner ungual teeth and do not differ from other individuals in the sample in any other character. Two southern populations (BLF4230 \& BLF5848) are characterized by having four inner ungual teeth, but otherwise are identical to populations from the north in the number of macrochaetae and other diagnostic characters. Two individuals from the north, one each from localities BLF9558 \& BLF3418 (type locality) also have four teethed-claws.

Although we do not dismiss the possibility that some of these forms represent different species (i.e., T. judithnajtae n. sp. could be a species complex), currently we do not have evidence to circumscribe them unambiguously. Determination of the significance of morphological variation may have to await a molecular analysis.

\section{Trogolaphysa monomaculata (Barra, 1969)}

Paronella (Microparonella) monomaculata Barra, 1969: 189, $212-$ 215, fig. 7A-K (Ipassa, Gabon).

Lepidonella monomaculata - Deharveng \& Bedos 1995: 22.

Trogolaphysa monomaculata - Soto-Adames \& Bellini 2015: 337.

TyPe LOCALITy. — Ipassa, Gabon.

Distribution. - Gabon.

\section{REMARKS}

Barra (1969) described this species in the subgenus Microparonella. Deharveng \& Bedos (1995) transferred all species assigned to Microparonella to the genus Lepidonella, but did not comment on the status of $L$. monomaculata. Soto-Adames \& Bellini (2015) transferred the species to Trogolaphysa based on the chaetotaxy $(2,3,3$ bothriotricha on abdominal segments $2-4$ and absence of head chaeta $\mathrm{Ps}_{3}$ ) illustrated by Barra (1969). The habitus (Barra 1969: fig. 7A), mucro (fig. 7J, K) and claw shape (fig. 7G, H, I) suggest the species was described based on immature specimens.

Trogolaphysa monomaculata is characterized by a uniformly light blue body, antennae, head, and legs, with a distinctive dark blue square band on $4^{\text {th }}$ abdominal segment; scales present on antennal segments 1-3 and on coxa, trochanter and femur of all legs; tenet hair long and weakly spatulate; unguis with 3 inner teeth, one paired tooth clearly larger than the other (Fig. 5D); unguiculus lanceolate; dens with two rows of ciliated spines; mucro rectangular, long, with 5 teeth.

This species is unique among African forms in having a broad band on $4^{\text {th }}$ abdominal segment and a long, fivetoothed mucro with teeth evenly distributed throughout its length. 
TABLE 2. - Diagnostic table for Trogolaphysa Mills, 1938 from Africa, Madagascar and the Seychelles: a, inferred from Mitra (2002c). Abbreviations and symbols: ?, character state unknown; Mc, macrochaetae; alternative, less frequent states are in parenthesis.

\begin{tabular}{|c|c|c|c|c|c|c|c|c|c|}
\hline $\begin{array}{c}\text { Character } \\
\text { species }\end{array}$ & $\begin{array}{l}\text { Dominant } \\
\text { color }\end{array}$ & Color pattern & $\begin{array}{l}\text { Paired dorsal } \\
\text { head Mc }\end{array}$ & $\begin{array}{l}\text { Th.2-Abd. } 4 \\
\text { inner Mc } \\
\text { formula }\end{array}$ & $\begin{array}{l}\text { Number } \\
\text { inner } \\
\text { teeth } \\
\text { unguis }\end{array}$ & $\begin{array}{l}\text { Position } \\
\text { paired } \\
\text { Teeth } \\
\text { unguis }\end{array}$ & $\begin{array}{l}\text { Shape } \\
\text { unguiculus }\end{array}$ & $\begin{array}{l}\text { Distal } \\
\text { Inner } \\
\text { dens } \\
\text { spines }\end{array}$ & $\begin{array}{c}\text { Number } \\
\text { teeth } \\
\text { mucro }\end{array}$ \\
\hline $\begin{array}{l}\text { T. beguei } \\
\text { n. comb. }\end{array}$ & white & $\begin{array}{l}\text { postocular band, all } \\
\text { Th. 3-Abd. } 2\end{array}$ & $?$ & $?$ & $4(3)$ & basal 1/4 & truncate & acuminate & 4 \\
\hline $\begin{array}{l}\text { T. fuelleborni } \\
\text { n. comb. }\end{array}$ & blue & no & $?$ & $?$ & 4 & distal 1/2 & lanceolate & acuminate & 4 \\
\hline $\begin{array}{l}\text { T. ghesquierei } \\
\text { n. comb. }\end{array}$ & yellow & no & $?$ & $?$ & 4 & basal 1/2 & lanceolate & acuminate & 4 \\
\hline $\begin{array}{l}\text { T. grassei } \\
\text { n. comb. }\end{array}$ & white & no & $?$ & $?$ & 3 & middle & lanceolate & acuminate & 3 \\
\hline $\begin{array}{l}\text { T. lamottei } \\
\text { n. comb. }\end{array}$ & white & $\begin{array}{l}\text { anterior 2/3 head; } \\
\text { Ant. 2-4; margin Th. } \\
\text { 2-Abd. 1; tibiotarsi }\end{array}$ & $?$ & $?$ & 4 & near middle & lanceolate & acuminate & 4 \\
\hline $\begin{array}{l}\text { T. judithnajtae } \\
\text { n. sp. }\end{array}$ & blue & no & $\begin{array}{l}7(8) \\
\text { A2, A3, A5, M2, } \\
\text { S3, (S4), S5, } \\
\text { Pa5 }\end{array}$ & $6(5-7) 0 / 0114$ & $3(4)$ & $\begin{array}{l}\text { middle } \\
\text { (basal 1/2) }\end{array}$ & lanceolate & acuminate & 4 \\
\hline \multicolumn{2}{|c|}{ T. monomaculata white } & $\begin{array}{l}\text { trapezoidal band } \\
\text { Abd. } 4\end{array}$ & $\begin{array}{l}1 ? \\
\mathrm{~A} 2\end{array}$ & $?$ & 3 & basal 1/2 & lanceolate & acuminate & 5 \\
\hline \multicolumn{2}{|c|}{$\begin{array}{l}\text { T. nigromaculata white } \\
\text { n. comb. }\end{array}$} & purple coxae & $\begin{array}{l}5 ? \\
\text { A2, A3, A5, S3, } \\
\text { S5a }\end{array}$ & $?$ & $3(4)$ & basal 1/2 & lanceolate & acuminate & 4 \\
\hline $\begin{array}{l}\text { T. penicillata } \\
\text { n. comb. }\end{array}$ & white & \multicolumn{2}{|c|}{ trasversal band Abd. $4 ?$} & $?$ & 4 & basal 1/2 & truncate & $\begin{array}{l}\text { paintbrush- } \\
\text { like }\end{array}$ & 4 \\
\hline T. vivieni & white & $\begin{array}{l}\text { banded Ant.; purple } \\
\text { metatrochanter }\end{array}$ & $\begin{array}{l}4 \\
\mathrm{~A} 2, \mathrm{M} 2, \mathrm{~S} 3, \mathrm{~Pa} 5\end{array}$ & $?$ & 3 & basal 1/2 & lanceolate & acuminate & 5 \\
\hline $\begin{array}{l}\text { T. wahlgreni } \\
\text { n. comb. }\end{array}$ & white & no & $\begin{array}{l}7 \\
\text { A2, A3, A5, M2, } \\
\text { S3, S5, Pa5 }\end{array}$ & $60 / 0114$ & 3 & middle & lanceolate & acuminate & 4 \\
\hline
\end{tabular}

\section{Trogolaphysa nigromaculata \\ (Schött, 1903) n. comb.}

Paronella nigromaculata Schött, 1903: IV, VII, pl. 1 fig. 8-11 (Bonge, Cameroon). - Wahlgren 1908: 2, 4, 6-8 (description, material used by Mitra 2002c to describe D. wahlgreni, Meru, Kenya). - Philiptschenko 1926: 192-193 (description, senior synonym of $P$. fuelleborni, Molo, British East Africa). - Schött 1927: 25, 27-30, pl. II figs 10-15 (redescription and description of variation, key to species, Debundscha, Cameroon). - Handschin 1929: 77: 16, 22-23, fig. 5 (descriptive notes, Ethiopia). — Denis 1933: 267, 268 (key to species, comments on variation reported in literature). - Delamare Debouteville \& Paulian 1952: 77 (mention, Ivory Coast). - Salmon 1956: 32-35, figs 88-102 (description, Rwanda, Burundi). — Paclt 1959: 56-58 (Neophorella dubia as junior synonym of T. nigromaculata, Natal, South Africa); 1967 : 142 (record, Tanzania). — Martynova 1961: 848, 854-857, fig. 5-7 (descriptive notes on variation, Ethiopia). - Mitra 2002c: 106, 109, 112 (syntypes deposited at the Swedish Museum of Natural History, Stockholm, descriptive notes on chaetotaxy, comparison with $D$. whalgreni).

Neophorella dubia Womersley, 1934: 464-465, fig. 12 (description, synonymyzed by Paclt 1959; Table Mount, Cape Town, South Africa).

Dicranocentruga nigromaculata-Mitra 1992: 212. — Mitra 2002c: 114, pl. I, fig. 1D (photo of slide-mounted syntype).

Type Locality. - Bonge, Cameroon.
Distribution. - Cameroon, Ivory Coast, Rwanda, Burundi, Tanzania, Ethiopia.

\section{REMARKS}

The description of Neophorella dubia Womersley, 1934 was based on a single individual collected in Cape Town, South Africa. Neither the original description of the species nor the accompanying figures recall or resemble a paronellid by any stretch of the imagination (habitus isotomid-like, with $3^{\text {rd }}$ abdominal segment longer than $4^{\text {th }}$ abdominal segment, dens twice as long as manubrium, scales absent, and mucro with three apical teeth). However, Paclt (1959) studied the holotype and indicated that the claw does resemble that of T. nigromaculata $\mathrm{n}$. comb., and that dental spines are present. Paclt (1959) did not mention the structure of the mucro. Ireson \& Greenslade (1990) re-examined the type specimen (and only known individual) of $N$. dubia and concluded that the species belongs in Tomoceridae Schäffer, 1896, as originally proposed by Womersley. Additional attempts to find the species at the type locality have been unsuccessful (Janion-Scheepers et al. 2015), but it seems safe to conclude that $N$. dubia does not belong in Trogolaphysa.

Trogolaphysa nigromaculata $\mathrm{n}$. comb. is transferred to Trogolaphysa on account of Mitra (2002c), who examined some types (see below) and placed the species in Dicranocentruga, a junior synonym of Trogolahysa (Soto-Adames \& Taylor 2013). 
Trogolaphysa nigromaculata $\mathrm{n}$. comb. is the most often reported and cited member of the genus in Africa, with putative distribution covering most of the tropical and southern subtropical regions of the continent. The original and subsequent descriptions by Schött $(1903,1927)$, although relatively extensive, provide few characters useful in distinguishing the widespread populations. The absence of a description of relevant diagnostic characters of the type material has lead authors to consider T. nigromaculata $\mathrm{n}$. comb. a very variable species.

The main diagnostic character of the species is related to the morphology of the unguis, which Schött (1903) described as having three inner teeth. However, samples including individuals with three or four inner ungual teeth was interpreted by various authors as intraspecific variation. Following this interpretation in claw variation the species was reported from Kenya (Whalgren 1908), Ethiopia (Philiptschenko 1926; Handschin 1929; Martynova 1961), Ivory Coast (Delamare Debouteville \& Paulian 1952), Rwanda and Burundi (Salmon 1956), and Tanzania (Paclt 1967).

It is unlikely that populations from such distant localities (which cover more than $7000 \mathrm{~km}$ ) and diverse environmental conditions (from the lowland tropical rain forest of Ivory Coast and Cameroon, to the highland forest of Rwanda and Burundi, and the xeric conditions of Ethiopia) represent the same species. Mitra (2002c) studied some syntypes of T. nigromaculata $\mathrm{n}$. comb. from Cameroon and individuals with three-toothed unguis from Kenya (originally identified as P. nigromaculata by Wahlgren 1908) and found the two populations to be easily distinguishable using head chaetotaxy. Extrapolating from Mitra's (2002c) observation, it is likely that variation in claw morphology reported in the literature reflects a mixture of species and that T. nigromaculata $\mathrm{n}$. comb. as currently delimited is a species complex.

The abbreviated description that follows is based on the original description by Schött (1903) with a few details of head chaetotaxy reported by Mitra (2002c). The redescription by Schött (1927) is unreliable because the material on which it is based was collected in Debundscha, not in the type locality of Bonge. Schött (1927) reports two color forms, the pale one matching the original description, and a dark one with more extensive blue pigment distributed along the flanks. In addition to differences in color pattern, the unguiculus in the dark form is truncate instead of lanceolate, and one of the inner paired ungual tooth is considerably longer than the other. The dark form is likely an unnamed species (Mitra 2002c might have been referring to these two forms when he pointed out that Schött's material from Cameroon and Wahlgren's material from Kenya includes three species).

The light form of $T$. nigromaculata $\mathrm{n}$. comb. is characterized by a whitish body, with dark blue pigment on all antennal segments, eye patch and coxae; head dorsally with five paired anterior macrochaetae (A2, A5, M2, S3, S5), paired posterior macrochaeta $\mathrm{Pa} 5$ absent; tenet hair somewhat short and spatulate; unguis with three inner teeth, basal teeth inserted on basal half of inner edge, unpaired tooth on distal half; unguiculus lanceolate; mucro square, quadridentate, with basal teeth paired.

\section{Trogolaphysa nigromaculata pallida}

(Delamare Debouteville in Delamare Debouteville \& Pauliani, 1952) n. comb

Paronella nigromaculata pallida Delamare Debouteville in Delamare Debouteville \& Pauliani, 1952: 77 (Le Banco, Ivory Coast).

Paronella nigromaculata pallida Delamare Debouteville, 1951: 209; nomen nudum.

Dicranocentruga nigromaculata pallida - Mitra 2002c: 114.

TyPe LOCAliTY. — Le Banco, Ivory Coast.

DisTRIBUTION. — Ivory Coast.

\section{REMARKS}

Delamare Debouteville (1951b) first mentions this taxon as a subspecies of $P$. nigromaculata, but only as a name in a table (1951b: 209). Since no description is attached to this name, P. nigromaculata pallida Delamare Debouteville, $1951 \mathrm{~b}$ is a nomen nudum. Delamare Debouteville again used the combination P. nigromaculata pallida in 1952, and this time states that the taxon is characterized by very sparse punctate blue pigment but with the same morphological characters as the nominal subspecies.

Paronella $n$. pallida was described on the same page as P. penicillata pallida (see below). If these two taxa turn out to be good species one of them will require a new epithet.

\section{Trogolaphysa penicillata (Schött, 1927)} n. comb.

Paronella penicillata Schött, 1927: 29-30, pl. II, fig. 16-20, key (Debundscha, Cameroon). - Denis 1933: 268, key. - Delamare Debouteville 1947: 453; 1948: 316, 421 (association with termite Noditermes curvatus, Ivory Coast); 1951b: 205, 209, 212, fig. 51 (Ivory Coast). — Delamare Debouteville in Delamare Debouteville \& Paulian 1952: 77 (Le Banco, Ivory Coast). — Barra 1969: 189 (record, Ipassa, Gabon). — Mitra 2002c: 106 (syntypes deposited at the Swedish Museum of Natural History, Stockholm).

Dicranocentruga penicillata - Mitra 1992: 212; 2002c: 114, 106, 114, fig. 3A (generic placement, incorrectly stating new combination, photo of syntype).

TyPe LOCAlity. - Debundscha, Cameroon.

Distribution. - Cameroon, Ivory Coast, Gabon.

\section{REMARKS}

This species is placed in Trogolaphysa based on the absence of manubrial spines and the shape of the mucro.

This species is restricted to Western Africa and is characterized by having a white background color, with blue pigment on lateral margin of the metathorax and 1 st abdominal segment, and a transversal band on anterior half of the $4^{\text {th }}$ abdominal segment; antennomere 1 light blue, all other antennal segments dark blue; tenet hair relatively long, and spatulate; unguis with 4 inner teeth, paired teeth inserted on basal half of inner edge; unpaired teeth shorter 

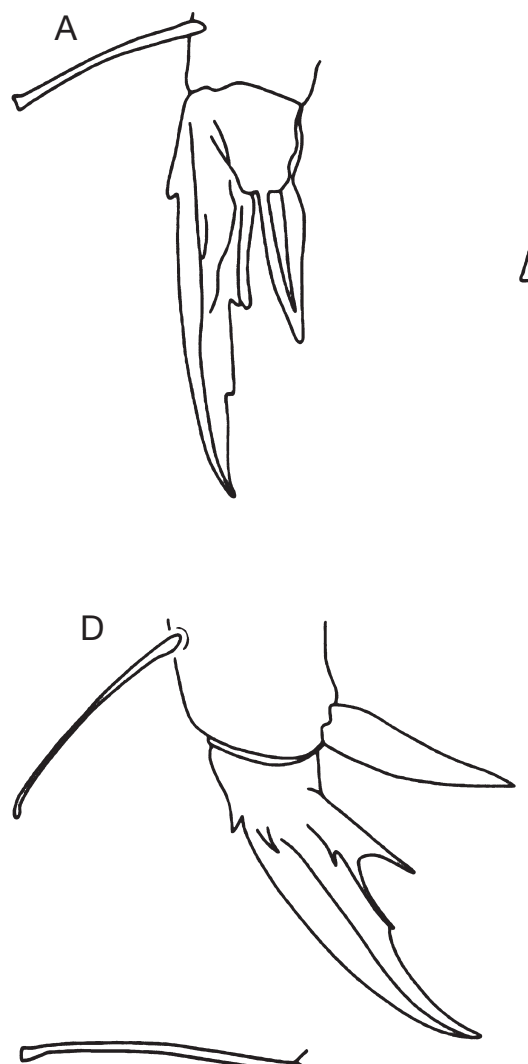
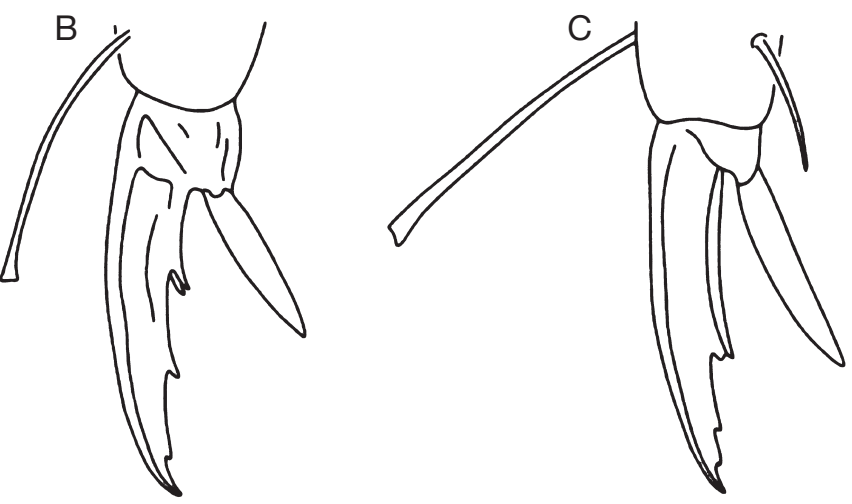

$\mathrm{F}$

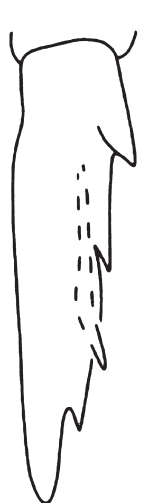

G

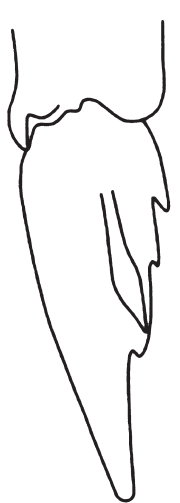

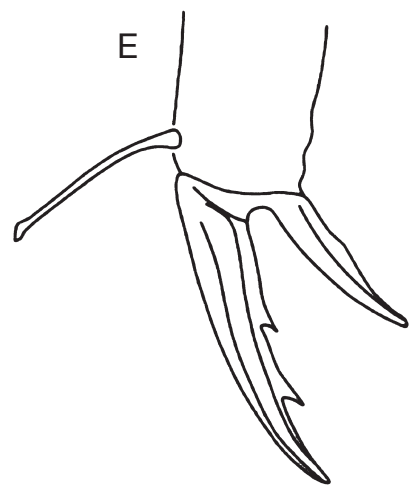

$\mathrm{H}$

I

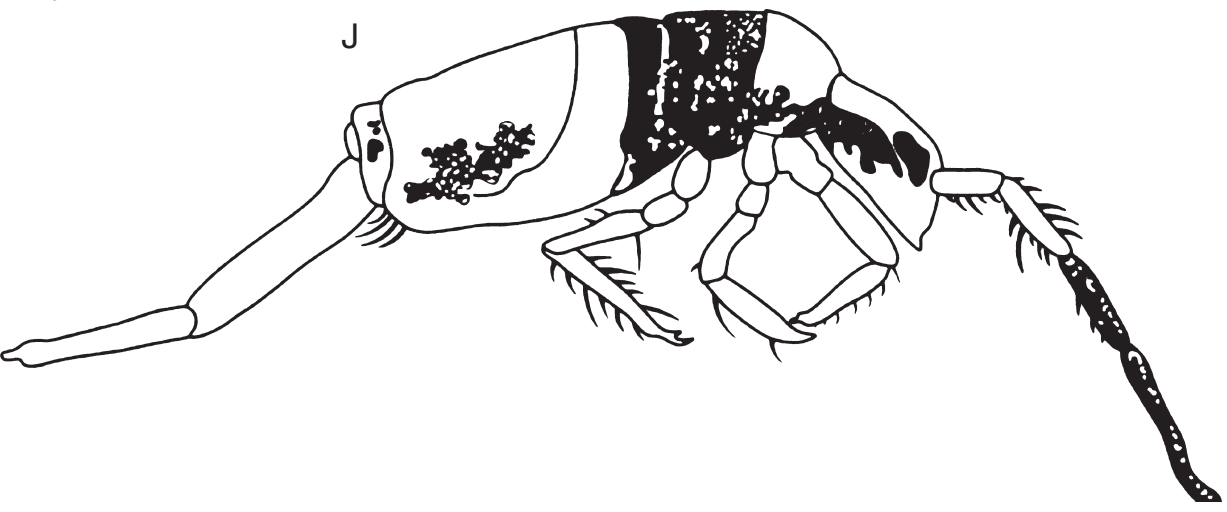

FIG. 5. - A, Trogolaphysa grassei (Delamare Debouteville, 1952) n. comb. hind claw form Delamare-Deboutteville (1952); B, T. ghesquierei (Marlier, 1945) n. comb. hind claw from Marlier (1945); C, T. fuelleborni n. comb. hind claw from Börner (1903); D, T. monomaculata, hind claw from Barra (1969); E, L. flava, hind claw from Carpenter (1916); F, T. monomaculata, mucro from Barra (1969); G, T. vivieni, mucro from Barra (1969); H, T. beguei (Delamare Debouteville, 1951) n. comb, hind claw complex, modified from Delamare Deboutteville (1951a); I, T. lamottei (Delamare Debouteville, 1950) n. comb. habitus, modified from Delamare Deboutteville (1950b); J, T. beguei n. comb. habitus, modified from Delamare Deboutteville (1951a). 
that paired teeth, inserted on distal half, far away from basal teeth; unguiculus truncate; dens with distal spines on inner row apically asymmetric and paintbrush-like; mucro with 4 teeth, basal teeth paired.

This species is easy to recognize by its distinctive color pattern, truncate unguiculus and the paintbrush-like distal dental spines.

\section{Trogolaphysa penicillata pallida}

(Delamare Debouteville in Delamare Debouteville \& Paulian, 1952) n. comb.

Paronella penicillata pallida Delamare Debouteville in Delamare Debouteville \& Paulian, 1952: 77 (Le Banco, Ivory Coast).

Dicranocentruga penicillata pallida - Mitra 2002c.

Type locality. - Le Banco, Ivory Coast.

Distribution. — Ivory Coast.

\section{REMARKS}

The types series of this subspecies was collected in the same sample as individuals of the nominal form (Delamare Debouteville \& Pauliani 1952), hence we transfer them to Trogolaphysa. According to the original description, this form lacks pigmentation along the lateral margin of thorax, and the pattern is limited to lateral spots on abdominal segment 4. Some individuals even lack the lateral pigment on abdominal segment 4 .

\section{Trogolaphysa vivieni (Barra, 1969)}

Paronella (Microparonella) vivieni Barra, 1969: 189, 207-212, fig. 6A-N (Ipassa, Gabon).

Lepidonella vivieni - Deharveng \& Bedos 1995: 22.

Trogolaphysa vivieni - Soto-Adames \& Bellini 2015: 337.

\section{REMARKS}

Like T. monomaculata, $T$. vivieni was originally described in Microparonella, transferred to Lepidonella by Deharveng \& Bedos (1995) and moved to Trogolaphysa by Soto-Adames \& Bellini (2015).

Trogolaphysa vivieni is characterized by a uniformly whitish body, with characteristic blue pigment on the basal half of antennomeres 2-3, all antennomere 4 and metathoracic trochanter; scales present on antennomeres 1-3 and on coxae, trochanter, and femur of all legs; tenet hair long and weakly spatulate; unguis with 3 inner teeth, paired teeth subequal; unguiculus lanceolate; dens with two rows of spines; mucro long, with 5 teeth, apical tooth much longer than all basal teeth.

This is the only white African species with dark blue pigment limited to the antennae and metatrochanter, and a five toothed mucro with a distinctly long apical tooth.

\section{Trogolaphysa wablgreni}

(Mitra, 2002) n. comb.

Dicranocentruga wahlgreni Mitra, 2002c: 109-113, figs 1-3, 5 (Meru, Kenya).

Paronella nigromaculata - Wahlgren 1908: 2, 4, 6-8 (wrong identification).

\section{REMARKS}

Mitra (2002c) described this species based on material Wahlgren (1908) identified as P. nigromaculata.

This species is characterized by being uniformly yellow or white, with pigment only on eye patch; labral papillae present; anterior head chaetotaxy with one unpaired (A0) and six paired (A2, A3, A5, M2, S3, S5) macrochaetae, posterior chaetotaxy with one paired macrochaeta (Pa5); mesothorax to $4^{\text {th }}$ abdominal segment with $60 / 0114$ inner macrochaetae; tenet hair long, strongly spatulate; unguis with 3 inner teeth, paired teeth inserted near middle of claw, one paired tooth slightly longer than other; unguiculus lanceolate; dens with one row of spines; mucro square, quadridentate.

This is a typical Trogolaphysa, and very similar to T. judithnajtae n. sp. (see diagnosis for that species). The original body macrochaetae map for abdominal segments 2-4 published by Mitra (2002c: 113) confounds symbols for macrochaetae and pseudopores, but once the confusion is resolved, the inner chaetotaxy is typical Trogolaphysa.

This is the only African species uniformly white or yellow having head macrochaetae M2 and S5, labral papillae, unguis with three inner teeth and one row of spines on dens.

Genus Lepidonella Yosii, 1960

Lepidonella flava (Carpenter, 1916)

Microparonella flava Carpenter, 1916: 43-44, figs 59-62; key (Seychelles). - Mitra 2002a: 67, 70 (generic status).

Paronella flava - Handschin 1928: 23. - Yoshii 1961: 195 (suggestion it may belong in Callyntrura Börner, 1906).

Callyntrura (Microparonella) flava - Jacquemart 1980: 8-9, fig. 3 (descriptive notes).

Lepidonella flava Deharveng \& Bedos 1995: 22, 23 (compared to Lepidonella lecongkieti Deharveng \& Bedos, 1995). - SotoAdames \& Bellini 2015: 332 (compared to Lepidonella zepellinii Soto-Adames \& Bellini, 2015).

TYPe LOCALiTy. — Mahé, Fôret noire, Seychelles.

Distribution. - Seychelles.

REMARKS

The generic assignment of this species is unclear. Carpenter (1916) originally placed the species in his newly described Microparonella. Handschin (1928) transferred M. flava to Paronella without providing a justification. Yoshii (1961), suggested the species could belong in Callyntrura, but did not propose a formal change (Yoshii could have confused $M$. flava 


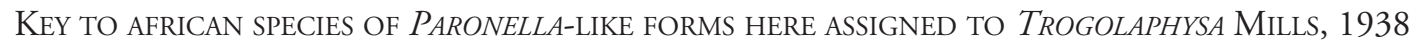

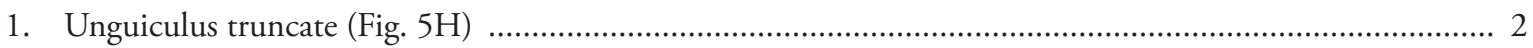

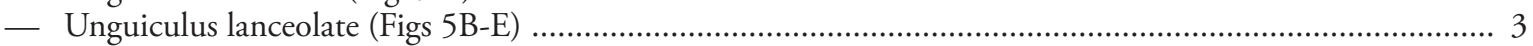

2. Metathorax to $2^{\text {nd }}$ abdominal segment uniformly dark blue (Fig. 5J); dens with inner row spines apically acuminate (Ivory Coast)

T. beguei (Delamare Debouteville, 1951) n. comb.

- Mesothorax to $2^{\text {nd }}$ abdominal segment never uniformly dark blue; dens with inner row spines apically asymmetrically ciliate, brush-like (Cameroon, Ivory Coast, Gabon) ............ T. penicillata (Schött, 1927) n. comb.

3. Mucro with 5 teeth (Fig. 5F)

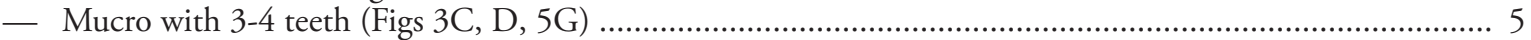

4. Abdomen 4 medially with dark blue square; unguis with one paired inner tooth clearly larger than other, much larger than proximal unpaired tooth; Mucro with basal teeth more or less evenly distributed (Fig. 5F) (Gabon) T. monomaculata (Barra, 1969)

- Abdomen 4 white, without marks; Unguis with paired inner teeth subequal, and not much larger than unpaired tooth; Mucro with basal teeth grouped on proximal end (Fig. 5G) (Gabon) T. vivieni (Barra, 1969)

5. Mucro with 3 teeth; tenet hair relatively short in relation to unguiculus (Fig. 5A); Unguis with 3 inner teeth (Ivory Coast) T. grassei (Delamare Debouteville, 1952) n. comb.

- Mucro with 4 teeth; tenet hair normally long in relation to unguiculus (Fig. 5B); Unguis with 3-4 inner teeth .... 6

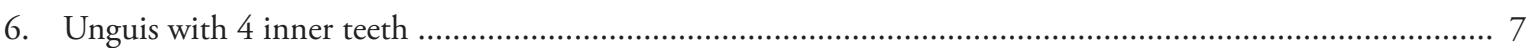

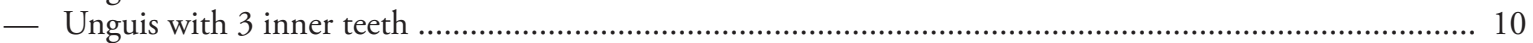

7. Antennomere 1 white, antennomeres 2-4 uniformly dark blue (Fig. 5I); femora white, tibiotarsi blue (Guinea) T. lamottei (Delamare Debouteville, 1950) n. comb.

- Antennomeres 1-2 white/yellow or light blue, antennomeres 3-4 darker; legs with all segments blue, brown or yellow

8. Unguis with all teeth inserted on distal half of inner edge (Fig. 5C) (Tanzania, Madagascar?) T. fuelleborni (Börner, 1903) n. comb.

— Unguis with basal teeth inserted on basal half \& unpaired teeth on distal half of inner edge (Fig. 5B) ........ 9

9. Body yellow (Republic of Congo) ................................................. T. ghesquierei (Marlier, 1945) n. comb.

- Body blue (Madagascar) T. judithnajtae n. sp.

10. Head macrochaetae A3 and Pa5 absent (Cameroon, Ivory Coast, Rwanda, Burundi, Tanzania, Ethiopia) T. nigromaculata (Schött, 1903) n. comb.

- Head macrochaetae A3 and Pa5 present (Fig. 2A) 11

11. Antennae, legs and body uniformly white; eye patch with up to 9 chaetae; Setiform labral papillae present; Dens with 1 row of spines (Kenya) T. wahlgreni (Mitra, 2002) n. comb.

- Antennae and legs uniformly dark blue, body with a general blue tint; eye patch with up to 6 chaetae; Setiform labral papillae absent; Dens with 2 row of spines (Madagascar) T. judithnajtae n. sp.

Carpenter, 1916 with Paronella flava Carpenter, 1917). In the Index to Collembola, Salmon (1964) transferred M. flava back to Paronella, under the assumption that Microparonella was a junior synonym of Paronella. Salmon (1964) noticed the homonymy with $P$. flava Carpenter, 1917 and renamed P. flava (Carpenter, 1916) as P. seychelliensis. Jacquemart (1980) concurred with Yoshii (1961) and formally proposed the combination Callyntrura (Microparonella) flava, even though the drawings he provides show a mucro similar to that in Paronellini or Bromacanthini rather than Callyntrurini.

Deharveng \& Bedos (1995) made it clear that M. caerulea Carpenter, 1916, the Type species of Microparonella, is a typical Troglopedetes, but at the same time pointed out that most species assigned to Microparonella do not belong in Troglopedetes.
Deharveng \& Bedos (1995) transferred most Microparonella to Lepidonella, including M. flava. Mitra (2002a) redescribed $M$. caerulea based on one syntype, concluded that Microparonella was a valid genus and retained the original combination $M$. flava. Unfortunately, the syntype studied by Mitra was missing antennal segments $2-4$ and he was unaware of the presence of a subdivision on the $4^{\text {th }}$ antennal segment, as pointed out by Deharveng \& Bedos (1995). In any case, the redefinition of Microparonella proposed by Mitra (2002a) is so general that it differs from the diagnosis of Trogolaphysa (sensu Thibaud \& Najt 1988 or Soto-Adames 2015) only in that Microparonella has smooth instead of striated or denticulate scales. Soto-Adames \& Bellini (2015) accepted Deharveng \& Bedos' (1995) opinion on the status of M. flava. 
Although L. flava was cited in the diagnosis of L. zeppelinit Soto-Adames \& Bellini, 2015, the species was inadvertently excluded from the key to Lepidonella of the World.

The original drawings of Carpenter (1916: plate 17, fig. 62), as well as the drawing by Jacquemart (1980) suggest this is either a Lepidonella or a Trogolaphysa with a 4-5 toothed, rectangular mucro. The few characters of the chaetotaxy described for the species are mostly ambiguous with respect to generic placement. Jacquemart's (1980) illustration of the dorsal head chaetotaxy is limited to macrochaetae, whereas the distinguishing characters between Lepidonella and Trogolaphysa are found in the distribution of microchaetae (Soto-Adames et al. 2014; Soto-Adames \& Bellini 2015). The absence of mesothoracic macrochaetae would suggest affinities to Lepidonella (some Lepidonella, such as L. zeppelini and L. marimuti Soto-Adames \& Bellini, 2015, carry mesothoracic macrochaetae, but whereas in Paronellini they are clustered near the pseudopore, in Lepidonella they are clearly close to the posterior margin of the segment). However, mesothoracic macrochaetae in Trogolaphysa are sometimes small and easily overlooked, especially if the specimens are old and opaque. The unusual distribution of bothriotricha (one on Abd. 2, three lateral and no inner on Abd. 3, and one on Abd. 4) illustrated by Jacquemart (1980), suggests the he might have missed the small sockets of mesothoracic macrochaetae. Most (all?) Paronellini have $4^{\text {th }}$ abdominal segment element B6 (in the sense of Soto-Adames 2015) modified into a meso-, or small macrochaeta inserted near element B5, whereas in Lepidonella, elements B5 and B6 are well separated, as in Lepidocyrtinae. Jacquemart's (1980) illustration of the $4^{\text {th }}$ abdominal segment shows that B5 and B6 are well separated and the organization of the inner macrochaetae is similar to L. zeppellini rather than to Paronellini. Based on this last character we retain this species in Lepidonella.

The diagnosis of this species is not well established, in part due to the morphological variation reported in the literature. The illustrations of the claw and mucro provided by Jacquemart (1980) differ from the original figures in Carpenter (1916): Carpenter shows a claw with basal teeth apparently subequal, and shorter than the unpaired tooth (Fig. 5E), whereas in Jacquemart one basal tooth is longer than the other and the longest of the pair is clearly longer than the unpaired tooth; in Carpenter's figure the mucro has 5 teeth and in Jacquemart it has four. Otherwise, it is probably easier to identify this species as the single unmarked (or weakly marked) yellow Lepidonella collected in the Seychelles.

\section{DISCUSSION}

The genus Trogolaphysa is distributed across the Neotropical (Soto-Adames \& Taylor 2013) and Afrotropical biogeographical regions, suggesting the group could have originated sometime between 160-120 mya. The fragmentation of Gondwaland around 150-160 mya separated Western (South America and Africa) and Eastern (Madagascar, India and Antarctica) Gondwana (Rabinowitz et al. 1983; Chatterjee \& Scotese 1999; de Wit et al. 1999) allowing for the evolution of groups, like Trogolaphysa and Campylothorax, uniquely shared by Africa and South America (Soto-Adames 2016). Given the geological relationships between Africa and Madagascar, the presence of T. judithnajtae n. sp. in the island is unexpected, although not altogether surprising. The similarity to T. wahlbergi from Kenya and remarkable morphological uniformity across its $1300 \mathrm{~km}$ range distribution point to a relatively recent introduction from Eastern Africa. It is interesting to note that a refined model of relationships between landmasses comprising Gondwanaland places Madagascar in wide contact with the region currently occupied by Kenya (and Tanzania, and Southern Somalia). However, a vicariant explanation for the origin of T. judithnajtae n. sp. would imply morphological stasis across at least 120 million years of evolution.

Most of the species level diversity in Trogolaphysa are found in the Neotropical region, but this may be an artifact of the intensity with which the genus has been studied in each region. The character systems that revealed the diversity of Neotropical Trogolaphysa species were developed recently and have not been applied to African forms. The diagnosis of African species is based almost exclusively on color pattern, claw and mucro morphology, that is, character systems that, among Neotropical species, are prone to convergent evolution (Soto-Adames 2015). The absence of additional character systems to distinguish African species has led to reports of some forms with distributions that comparatively make those of Neotropical species very limited. Some Mexican species have distributions measured in hundreds of kilometers (Soto-Adames 2015), but the distribution of T. nigromaculata n. comb. is counted in the thousands of kilometers. The large range distribution of T. nigromaculata n. comb. in Africa may be interpreted in two ways: a) the genus invaded Africa from South America and it has not diversified extensively, particularly on Eastern Africa; or b) most species diversity has been obscured by the poor state of the taxonomy of the group in the region.

The diversity of species in Africa shows a gradient leading from high density in the west to low density in the east. Of the twelve continental species, nine have been reported from Africa west of the Congo River Basin. Before Mitra's (2002c) study, only T. nigromaculata $\mathrm{n}$. comb. was known from East Africa. The difference in diversity between Eastern and Western Africa does not seem to be an artifact of collection effort since the number of general collection sites is approximately the same for both regions (judging from the number of samples implied by the synonymy). The pattern of diversity, with more species on western than eastern Africa, is what we would expect to see if Trogolaphysa invaded Africa from South America (or from the area shared by the two continents before their separation some 130 million years ago) and expanded eastward. An additional factor that might have affected species level diversity across the continent is general climate. The eastern slope of the continent has a dryer climate than the western slope and, given that Trogolaphysa seem to prefer moist forest leaf litter, it is possible that diversification in Eastern Africa dry forests has been slower. 
An alternative explanation is that the difference in species diversity between the Neotropics and Africa, and across Africa itself, may be an artifact of the poor state of the taxonomy of the group in the region. It may be that the actual diversity of African Trogolaphysa has been obscured because of neglect by taxonomists. It is possible that once the recently developed character systems are examined, many allopatric populations originally determined as T. nigromaculata $\mathrm{n}$. comb. will be shown to represent different species. The analysis by Mitra (2002c) provides an example. Wahlgren (1908) identified individuals collected in Meru, Kenya as T. nigromaculata n. comb., but Meru is c. $2860 \mathrm{~km}$ southeast of Bonge, Cameroon, the type locality for the species. Mitra (2002c) compared the Kenyan material identified by Wahlgren with syntypes from Cameroon and found clear differences in the dorsal chaetotaxy of the head, leading him to describe T. wahlgreni n. comb. Thus, it is clearly necessary to consider additional character systems to be able to determine the real diversity of species in Africa.

The tempo and mode of evolution of chaetotaxy and other morphological characters in Paronellini pose an interesting problem. The level of stasis in chaetotaxy organization of Trogolaphysa lineages across both side of the Atlantic Ocean is remarkable. Despite their presumably long independent evolution, there are no morphological characters to distinguish between Neotropical and African lineages. In general, the organization of the main elements of the dorsal chaetotaxy of the body in T. judithnajtae n. sp. and T. wahlgreni n. comb. is identical to the organization in Neotropical forms. The East African species have two characters on the head chaetotaxy that are rare in Neotropical species, a well-marked macrochaeta A5, and macrochaeta An3p1i. However, in T. vivieni from Gabon the condition of A5 and An3p1i is as in the Neotropical species, in that, when present, they are rarely developed into macrochaetae. Given the absence of an all-encompassing distinction between African and Neotropical lineages within Trogolaphysa, it would be interesting to compare interspecific variation in the genera Troglopedetes and Cyphoderopsis, two Paronellini with a much wider geographic range than either Trogolaphysa or Campylothorax (Thibaud \& Najt 1988; Deharveng \& Gers 1993; Jantarit et al. 2013; Soto-Adames 2016). Analysis of the pattern of morphological variation in Paronellini across biogeographic regions could prove valuable in helping us understand the tempo of evolution in soil microarthropods.

\section{Acknowledgements}

We dedicate this work to Judith Najt, in recognition of her important contributions to the systematics of Collembola. We would like to thank the late Norman Penny for making available the collection of springtails from the California Academy of Sciences Madagascar expeditions. We also thank Andrew Suarez and Carol Augspurger for providing space to develop this project; Aron Katz helped with rudiments of Adobe Illustrator; and Rosanna Giordano supported the senior author during the final phase of research. We express our gratitude to the reviewers, who took the time to read the manuscript carefully and to provide valuable constructive criticism.

\section{REFERENCES}

Barra J.-A. 1969. - Collemboles du Gabon. Revue Biologia Gabonica 5: 189-216.

Bellinger P. F., Christiansen K. A. \& Janssens F. 1996-2017. Checklist of the Collembola of the World. http://www.collembola.org. Last accessed 3 February 2018.

BÖRNER C. 1903. - Über neue Altweltliche Collembolen, nebst Bermerkungen zur Systematik der Isotominen und Entomobryinen. Gesellschaft naturforschender Freunde: 129-182.

BÖRNER C. 1906. — Das System der Collembolen nebst Beschreibung neuer Collembolen des Hamburger Naturhistorischen Museums. Mitteilungen aus dem Naturhistorischen Museum 23: 147-188.

Carpenter G. H. 1916. - The Apterygota of the Seychelles. Proceedings of the Royal Irish Academy 33: 1-108.

CARPENTER G. H. 1917. - Collembola, zoological results of the Abor expedition, 1911-12. Records of the Indian Museum 8: 561-568.

Chatterjee S. \& SCOtese C. R. 1999 - The breakup of Gondwana and the evolution and biogeography of the Indian Plate PINSA 65A: 937-425.

Christiansen K. \& Bellinger P. 1998. - The Collembola of North America North of the Rio Grande; A Taxonomic Analysis. $2^{\text {nd }}$ ed., Grinnell College, Grinnell, Iowa, 1518 p.

Deharveng L. \& Gers C. 1993. - Ten new species of Troglopedetes Absolon 1907, from caves of Thailand (Collembola Paronellidae). Bijdragen tot de Dierkunde 63: 103-113

Delamare Deboutteville C. 1947. - Cycle évolutif d'un peuplement nidicole en Basse Côte-d'Ivoire. Bulletin du Museum 19: 453-455.

Delamare Deboutteville C. 1948. — Recherches sur les Collemboles termitophiles et myrmécophiles (Écologie, Ethologie, Systématique). Archives de Zoologie expérimentale et générale 85: 265-425.

Delamare Deboutteville C. 1950a. - Salina insignis (Handschin) Collembole commensal d'un Thysanoptera a Madagascar. Naturaliste Malgache 2: 103-109.

Delamare Deboutteville C. 1950b. - Deux nouvelles espèces de collemboles du Mont Nimba (Guinée française) récoltées par M. Maxime Lamotte. Bulletin de la Société zoologique de France 75: 43-45.

Delamare Deboutteville C. 1951a. - Nouveaux Paronelliens de la Côte d'Ivoire. Bulletin de l'Institut francaise d'Afrique noire 13: $1072-1075$.

Delamare Deboutteville C. 1951b. - Microfaune du sol des pays tempérés et tropicaux. Actualités scientifiques et industrielles 1160: 1-360.

Delamare Deboutteville C. 1952. - Trois nouvelles espèces de Collemboles de la Côte d'Ivoire. Revue française d'Entomologie 19: 240-243.

Delamare Deboutteville C. \& Paulian R. 1947. - Cycle évolutif d'un peuplement nidicole en Basse Côte d'Ivoire. Bulletin du Muséum national d'Histoire naturelle 2: 453-455.

Delamare Deboutteville C. \& Paulian R. 1952. - Recherches sur la faune des nids et des terriers en Basse Côte d'Ivoire. Chapitre VIII, Étude systématique. I. - Collembola. Encyclopédie biogéographique et écologique 8: 62-77

DeharVeng L. \& Bedos A. 1995. - Lepidonella lecongkieti n. sp., première Collembole cavernicole de Vietnam. Bulletin de la Société entomologique de France 100: 21-24.

DENIS J. R. 1933. - Contributo alla conoscenza del "microgenton" di Costa Rica, III. Collemboles de Costa Rica avec une contribution au species de l'ordre (deuxieme note). Bolletino del Laboratorio di Zoologia Generale e Agraria Portici 27: 222-322.

HANDSCHIN E. 1928. - Collemboles aus Java, nebst einem beitrag zu einer monographie der gattung Crematocephalus Schtt. Treubia 10: 245-270.

HANDSCHIN E. 1929. - Collembola from Abyssinia. Transactions of the Entomological Society of London 77: 15-28. https://doi. org/10.1111/j.1365-2311.1929.tb00678.x 
Ireson J. E. \& Greenslade P. 1990. — Lasiofinus gen. n. (Collembola: Tomoceridae) from Tasmania and re-examination of Neophorella dubia Womersley (Tomoceridae). Journal of the Australian Entomological Society 29: 205-214. https://doi.org/ 10.1111/j.1440-6055.1990.tb00350.x

JACQUEMART S. 1980. - Collemboles entomobryens nouveaux d'Afrique centrale. Bulletin de l'Institut royal des Sciences naturelles de Belgique 52: 1-15.

Janion-Scheepers C., Deharveng L., Bedos A. \& Chown S. 2015. - Updated list of Collembola species currently recorded from South Africa. Zookeys 503: 55-88. https://doi.org/10.3897/ zookeys. 503.8966

Jantarit S., SATASOOK C. \& Deharveng L. 2013. - The genus Cyphoderopsis Carpenter (Collembola: Paronellidae) in Thailand and a faunal transition at the Isthmus of Kra in Troglopedetinae. Zootaxa 3721: 049-070. https://doi.org/10.11646/ zootaxa.3721.1.2

MARi MutT J. A. 1979. - A revision of the genus Dicranocentrus Schött (Insecta: Collembola: Entomobryidae). Agricultural Experiment Station University of Puerto Rico, Bulletin 259: 1-79.

MARLIER G. 1945. — Collemboles du Congo belge. Revue de Zoologie et de Botanique africaines 38: 252-264.

Martynova E. F. 1961. - Materials on the fauna of Collembola of Ethiopia. Revue d'Entomologie de l'USSR 40: 848-857.

Mills H. B. 1938. - Collembola from Yucatan Caves. Carnegie Institution of Washington Publication 491: 183-190.

Mitra S. K. 1992. - Fixation of the concept of Paronella Schött, 1893 [Collembola: Entomobryidae]. Records of the Zoological Survey of India 92: 211-224.

Mitra S. K. 2002a. - Status of Microparonella Carpenter, 1916 (Collembola: Entomobriyidae: Paronellinae). Records of Zoological Survey of India 100: 67-72.

MitRa S. K. 2002b. — Resuscitation of Trichorypha Schött, 1893 (Collembola: Entomobryidae). Records of the Zoological Survey of India 100: 99-104.

Mitra S. K. 2002c. - Status of Dicranocentruga Wray, 1953 with the description of a new species (Collembola: Entomobryidae). Records of the Zoological Survey of India 100: 105-116.

PACLT J. 1959. — Collembola. South African Animal Life 6: 24-78.

PAClT J. 1967. - On South and Central African Collembola Journal of the Entomological Society of South Africa 29: 135-147.

PHILIPTSCHENKO J. 1926. - On the Collembola collected by the expedition of V. A. Dogiel and I. I. Sokolov in British East Africa. Revue russe d'Entomologie 20: 180-196.

Rabinowitz P. D., Coffin M. F. \& Falvey D. 1983 - The separation of Madagascar and Africa. Science 220: 67-69. https://doi. org/10.1126/science.220.4592.67

SALMON J. T. 1956. - Contribution à l'étude de la faune entomologique du Ruanda-Urundi (Mission P. Basilewsky 1953): LXXIX. Collembola. Sciences zoologiques 51: 9-40.

Salmon J. T. 1964. - An index to the Collembola. Royal Society of New Zealand Bulletin 7: 145-644.

SсHÖтT H. 1893. - Beiträge zur Kenntnis der Insektenfauna von Kameroon. I. Collembola. Bihang till Kongliga Svenska VetenskapsAkademien Handligar 19: 1-28.

Sснӧтт H. 1903. — Uber zwei Gattungen der Apterygoten Insekten. Redogorelse for Allamanna Larvorken I Linkoping. Esko och Vadstena. Underlarsaret: 3-16.

SснÖтт H. 1927. — Kamerunische Collembola. Medd. Linköpings Högre Allmänna Läroverk redogörelse: 1-39.

Silva D. D. DA \& BELLini B. C. 2015. - Trogolaphysa formosensis n. sp. (Collembola: Paronellidae) from Atlantinc fores, Northeaest regioof Brazil. Zoologia 32: 53-58. https://doi.org/10.1590/ S1984-46702015000100008

Soto-Adames F. N. 2008. - Postembryonic development of the dorsal chaetotaxy in Seira dowlingi (Collembola, Entomobryidae); with an analysis of the diagnostic and phylogenetic significance of primary chaetotaxy in Seira. Zootaxa 1683: 1-31.
Soto-Adames F. N. 2015. - The dorsal chaetotaxy of first instar Trogolaphysa jataca, with description of twelve new species of Neotropical Trogolaphysa (Hexapoda: Collembola: Paronellidae). Zootaxa 4032: 1-41. https://doi.org/10.11646/zootaxa.4032.1.1

Soto-Adames F. N. 2016. - Chaetotaxy of first-instar Campylothorax sabanus (Wray), and description of three new Campylothorax species from Hispaniola (Collembola, Paronellidae). Journal of Natural History 50: 1583-1612. https://doi.org/10.1080/0022 2933.2016.1145272

Soto-Adames F. N. \& Bellini B. C. 2015. - Dorsal Chaetotaxy of neotropical species supports a basal position for the genus Lepidonella among scaled Paronellidae (Collembola, Entomobryoidea). Florida Entomologist 98: 330-341. https://doi. org/10.1653/024.098.0152

SotO-Adames F. N. \& TAYlor J. T. 2013. - Chaetotaxy and character evolution in Trogolaphysa (Collembola, Entomobryoidea, Paronellidae), with descriptions of two new species from caves in Belize. Zookeys 323: 35-74. https://doi.org/10.3897/ zookeys.323.4950

Soto-Adames F. N., Barra J. A., Christiansen K. \& Jordana R. 2008. - Suprageneric Classification of the Entomobryomorph Collembola. Annals of the Entomological Society of America 101: 501-513. https://doi.org/10.1603/0013-8746(2008)101[501:SCO $\mathrm{CE}] 2.0 . \mathrm{CO} ; 2$

Soto-Adames F. N., Jordana R. \& Baquero E. 2014. - Comparative analysis of the dorsal chaetotaxy of Troglopedetes, Trogolaphysa and Campylothorax supports the synonymization of tribes Paronellini and Troglopedetini (Collembola: Paronellidae). Journal of Insect Science 14: 278-293. https://doi.org/10.1093/ jisesa/ieu 140

THIBAUD J.-M. 2013. - Essay on the state of knowledge of collembolan diversity in the African-Malgasy Region. Russian Entomological Journal 22: 233-248.

Thibaud J.-M. \& NajT J. 1988. - Collemboles (Insecta) de l'Equateur IV. Paronellidae avec révision de quarter genres. Bulletin du Museum national d'Histoire naturelle 4: 719-730.

WAHLGREN E. 1908. — Wissensch Ergebn. der Schwed Zoolog. Exp nach dem Kilimandjaro, dem Meru 1905-1906. Unter Leitung von Prof. Dr. Yngve Sjostedt. 18: Apterygogenea 1. Collembola: 1-10.

WiLSON M. J. 1982. - A review of world Troglopedetini (Insects, Collembola, Paronellidae) including an identification table and description of new species. Transactions of the British Cave Research Association 9: 210-226.

Wit M. De, JefFrey M., Bergh H. \& Nicolaysen L. 1999. — Gondwana reconstruction and dispersion. Search and Discovery 30001: 1-9. http://www.searchanddiscovery.com/documents/97019/ index.htm

WomersLey H. 1934. - On some Collembola Arthropleona from South Africa and Southern Rhodesia. Annals of the South African Museum 3: 441-475.

Yoshi R. 1961. - On some Collembola from Thailand. Nature and Life in Southeast Asia 1: 169-205.

Yoshi R. 1966. - On some Collembola of Afghanistan, India and Ceylon, collected by the Kuphe-expedition, 1960. Results of the Kyoto University Scientific Expedition to the Karakoram and Hindukush, 1955 8: 333-405.

Zon D. S., Thibaud J. M. \& TANO Y. 2013. - États des connaissances sur les Collemboles de Côte d'Ivoire (Afrique de l'ouest) (Collembola). Russian Entomological Journal 22: 91-96

Submitted on 16 August 2016; accepted on 6 February 2018; published on 23 May 2018. 